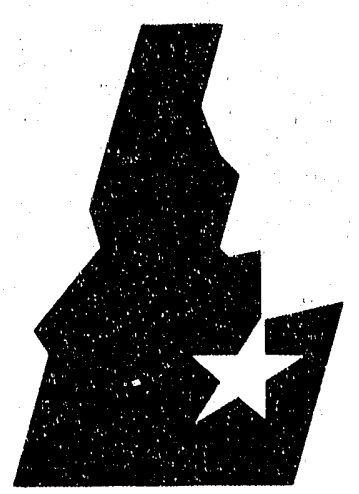

Idaho

National
EGG-WTD-10056

January 1992

APR 271992

\title{
Summary of INEL Research on the
} Iron-Enriched Basalt Waste Form

\section{Engineering}

Laboratory

Managed

by the U.S.

Department

of Energy

\author{
G. A. Reimann \\ J. D. Grandy \\ T. L. Eddy \\ G. L. Anderson
}

\section{$\lim _{0}$ EEs Idaho}

Work performed under
DOE Contract No DE-ACO7-761D01570 
This document contains new concepts or the author(s) interpretation of new calculations and/or measurements; accordingly, EG\&G Idaho, Inc. is required by the Inited States Government to include the following disclaimer:

\section{DISCLAIMER}

This report was prepared as an account of work sponsored by an agency of the United States Government. Neither the United States Government nor any agency thereot, nor any of their employees, makes any warranty, express or implied, or assumes any legal liability or responsibility for the accuracy, completeness, or usefulness of any infermation, apparatus, product or process disclosed, or represents that its use would not infringe privately owned rights. References herein to any specific commercial product, process, or service by trade name, trademark, manufacturer, or otherwisie, does not necessarly constitute or imply its endorsement, recornmendation, or favoring by the United States Government or any agency thereol The views and opinions of authors expressed herein do not necessarily state or reflect those of the United States Government or any agency thereof. 


\title{
Summary of INEL Research on the Iron-Enriched Basalt Waste Form
}

\author{
G. A. Reimann \\ J. D. Grandy \\ T. L. Eddy \\ G. L. Anderson
}

Published January 1992
Idaho National Engineering Laboratory
EG\&G Idaho, Inc.
Idaho Falls, ID 83415
Prepared for the
U.S. Department of Energy
Office of Environmental Restoration and Waste Management Under DOE Idaho Field Office Contract DE-AC07-76ID01570

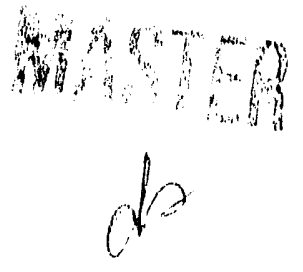


Summary of INEL Research on the Iron-Enriched Basalt Waste Form

Prepared by:
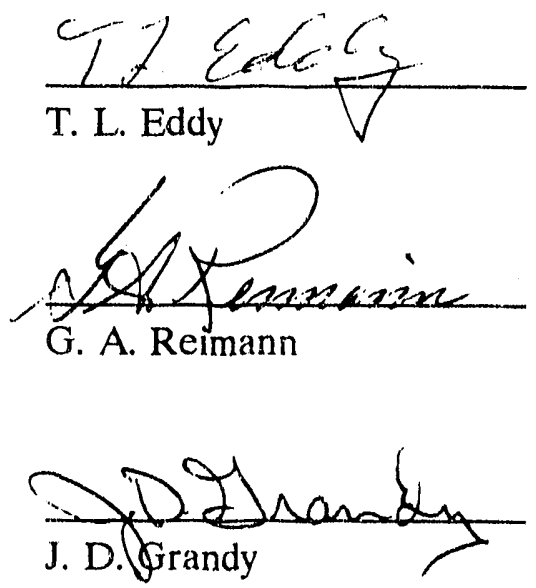

Reviewed by:

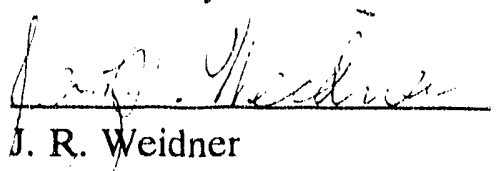

Serape

S. O. Bates
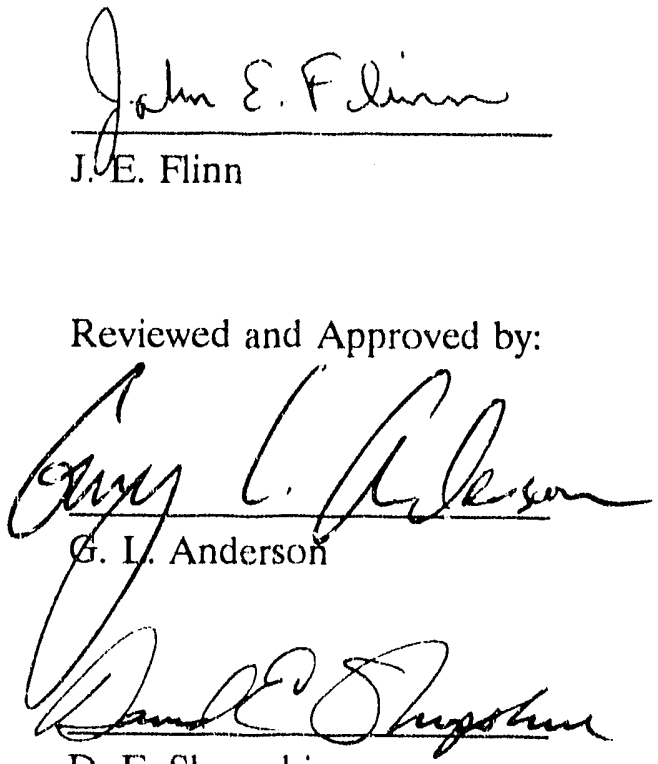

D. E. Shropshire
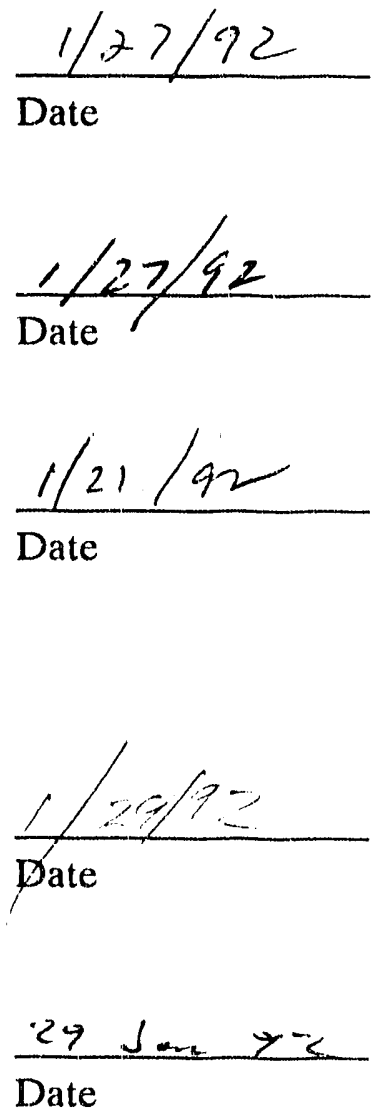

$\operatorname{Jan} .29,1992$

Date

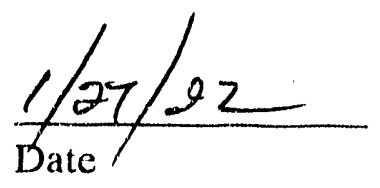

$1 / 29 / 92$

Date 


\begin{abstract}
This report summarizes the knowledge base on the iron-enriched basalt (IEB) waste form developed at the Idaho National Engineering Laboratory (INEL) during 1979-1982. The results presented discuss the applicability of IEB in converting retrieved transuranic (TRU) waste from INEL's Radioactive Waste Management Complex (RWMC) into a vitreous/ceramic (glassy/rock) stable waste form suitable for permanent disposal in an appropriate repository, such as the Waste Isolation Pilot Plant (WIPP) in New Mexico. Borosilicate glass (BSG), the approved high-level waste form, appears unsuited for this application. Melting the average wastc-soil mix from the RWMC produces the IEB composition and attempting to convert IEB to the BSG composition would require additions of substantial $\mathrm{B}_{2} \mathrm{O}_{3}, \mathrm{Na}$, and $\mathrm{SiO}_{2}$ (glass frit). IEB requires processing temperatures of 1400 to $1600^{\circ} \mathrm{C}$, depending upon the waste composition. Production of the IEB waste form, using Jouleheated melters, has proved difficult in the past because of electrode and refractory corrosion problems associated with the high temperature melts. Higher temperature electric melters (arc and plasma) are available to produce this final waste form. Past research focused on extensive slag property measurements, waste form leachability tests, mechanical, composition, and microstructure evaluations, as well as a host of experiments to improve production of the waste form. Past INEL studies indicated that the IEB glass-ceramic is a material that will accommodate and stabilize a wide range of heterogeneous waste materials, including long lived radionuclides and scrap metals, while maintaining a superior level of chemical and physical performance characteristics. Controlled cooling of the molten IEB and subsequent heat treatment will produce a glass-ceramic waste form with superior leach resistance. Recommended future work includes studies on 1) the retention and dissolution of TRU oxides in the IEB slag in solid solution with zirconia or equivalent, 2) the disposition of the high vapor pressure metals, including $\mathrm{Cs}, \mathrm{Pb}$, and $\mathrm{Hg}, 3$ ) the controlled cooling process necessary to obtain the appropriate fine-grained crystalline structure necessary for minimum leaching of radionuclides and toxic substances, 4) processing with plasma-torch and/or arc-heated melters in an attempt to overcome process temperature-related problems experienced with the Jouleheated melter, and to detect at lab scale any rotor processing problems.
\end{abstract}




\section{EXECUTIVE SUMMARY}

This report summarizes the research on iron-enriched basalt (IEB) that was performed at the INEL between 1979 and 1982. The IEB study evaluated the suitability of the basaltic waste form for immobilization of radionuclides and toxic substances. The purpose of this report is to review the significant results of the IEB research and to examine the applicability of these results and the IEB waste form to the RWMC buried wastes.

Several million cubic feet of TRU-contaminated wastes are in temporary storage and buried at the RWMC. This waste must be retrieved and the TRU element contaminated waste streams converted into a stable waste form before shipment to a repository for permanent disposal. Borosilicate glass (BSG) has been approved as a final waste form for stabilizing high-level wastes. BSG is produced in a low-temperature $\left(1000-1200^{\circ} \mathrm{C}\right)$ Joule-heated melter. The high metal content of TRU waste materials and the accompanying contaminated soil will require a high-temperature $\left(1400-1600^{\circ} \mathrm{C}\right)$ Joule-, arc-, or plasma-heated melter; first to melt the iron and other metals to facilitate oxidation, and second to maintain appropriate slag viscosity and fluidity. The slag obtained is a high-temperature ferro-alumina-silicate ceramic (rock), otherwise known as IEB, which possesses equivalent or superior physical and chemical durability compared to other glass-ceramics or glasses such as BSG. Attempting to use BSG for RWMC wastes would require excessive additives $\left(\mathrm{B}_{2} \mathrm{O}_{3}\right.$ and $\mathrm{SiO}_{2}$ ) to dilute the iron and aluminum oxides and would result in an increase in waste form volume instead of the desired reduction. Thus, an increasing interest has developed in reviving knowledge about IEB as a waste form and determining what should be investigated relative to processing of wastes into IEB.

Information summarized in this report was obtained from INEL Informal Reports, Internal Technical Reports, and conference and journal publications generated during the INEL's 1979-1982 study on IEB. Archival material, laboratory notebooks, and notes were reviewed. Available participating personnel were also interviewed. Particularly valuable were the 1981 Annual Report, program technical review presentations, and the review committee response.

This survey reviews INEL IEB research on enhanced uranium and TRU retention as a result of devitrification, leaching characteristics of IEB as improved by crystallization (devitrification), cesium volatility due to elevated melt temperatures, extensive measurements of slag properties at the elevated temperatures required, and solubility limits of various materials in the slag. Also reviewed are various melter characteristics and associated operational problems with Joule heated melters, such as refractory and electrode corrosion at the elevated temperatures required, migration of radionuclides into refractories, and enhanced oxidation and dissolution of molten metals. A brief discussion of the results follows. 


\section{Uranium \& TRU Retention}

The IEB studies confirmed that uranium and various TRU materials were relatively easily oxidized (compared to iron and other metals) in IEB slag materials with different ratios of average TRU waste to RWMC soil. Leach rates for the uranium and the TRU oxides in IEB have been found to be both higher and lower than from BSG. This apparent contradiction seems to be due to not normalizing test results and variations in the test procedures. Further studies indicated that the introduction of $\mathrm{ZrO}_{2}$ enables development of host crystals which incorporate uranium oxide into their structure during devitrification and which form highly leach resistant materials. With controlled cooling of IEB, a very fine crystalline structure was developed, whichi produced much smaller leach rates than $\mathrm{BSG}$. Without the presence of $\mathrm{ZrO}_{2}$, uranium precipitates as a separate oxide in the residual glass phase and among the other crystalline phases with an unmeasurable amount dissolved within the glass phase. Plutonium behaves in a similar manner. Under this condition, the uranium oxide was found to leach more rapirlly than when in solid solution with $\mathrm{ZrO}_{2}$. While affinity of the zirconia for uranium was demonstrated, the affinity for $\mathrm{Pu}$ and other TRUs was not determined. Although it is expected that the TRUs will behave in a manner similar to uranium, this speculation remains unproven.

\section{Cesium Volatility}

The temperatures required for melting the IEB composition are quite high $\left(1400-1600^{\circ} \mathrm{C}\right)$ and cesium was expected to evaporate from the melt at a rapid rate due to the relatively high vapor pressure of its oxide. However, tests did not support this expectation as much of the sesium remained in the slag. Other metals and metal oxides are volatile under these conditions and provisions must be incorporated into the furnace offgas system to capture and rotain these oxides. This subject warrants further research.

\section{Determination of Slag Properties}

A variety of molten IFB slag properties were examined over the wide range of compositions that defined the IEB waste form and over a broad range of temperatures. Viscosity and electrical conductivity were measured over the range of relevant composition and temperature as a guide for maintaining successful melter operation under various conditions. Solubility limits of various oxides in the IEB product microstructure were determined. A significant amount of aluminum scrap in the charge was found to generate excessive alumina causing the melt to freeze, as expected. The presence of metal fluorides improved viscosity but accelerated refractory corrosion. Lower bath temperature improved refractory life, but tended to cause undesirable crystallization (precipitation) from the melt and development of a cumulate layer on the furnace bottom. 


\section{Melter Characteristics, Problems}

Much of the research was performed in crucible tests, but the INEL pilot-scale work was done in a Joule-heated melter. This concept is used normally for producing BSG and it appeared adaptable to IEB production. The higher melting temperatures needed for IEB required Mo electrodes (that corrode in the environments needed to oxidize metals) and more corrosion-resistant refractories, compared to the low-temperature glass melters with Inconel electrodes. Ruby refractory brick was found to work best, but it still corroded near the slag-air interface. Electrode oxidation was significant but could be overcome by periodically feeding electrodes into the melt during the runs. At elevated temperatures, the refractory may become conducting and some current will begin to flow through the furnace walls instead of the melt. A small (9 liter) melter operated (continuously at temperature) 2,252 hours using water-cooled melter walls and nitrogen-blanketed electrodes. Melter durability could be improved with some design modifications, especially with regard to protecting Mo electrodes from oxidation. Some of the early slag samples analyzed for microstructure and leaching were produced in slagging-pyrolysis incinerators, in joule-heated melters, and in electric arc furnaces operated elsewhere. Each of these systems had operational problems, the resolution of which were beyond the scope of this study. No experimental studies of plasma or arc-heated melters was made at INEL on IEB research.

Laboratory tests showed that uranium did not tend to migrate into or otherwise accumulate in the refractories. Bubblers in the furnace bottom would hasten oxidation and solution of accumulated metals, but some provisions must be made to prevent plugging of the bubblers. In crucible tests, molten metals, particularly iron, would settle to the bottom of the melt and gradually oxidize so that they could be dissolved by the IEB. A bubbler dramatically increased the oxidation rate successively when argon, air, and pure oxygen was used. Development of reducing conditions would tend to reduce some metals from the oxide phase of the bath and return them to the bottom of the furnace.

\section{Conclusions and Recommendations}

The IEB glass-ceramic has been shown to be a superior waste form but an effective technology to produce it has not been demonstrated. For the near term it is recommended that available resources be concentrated on the effort necessary to qualify IEB to meet the TRU storage requirements for WIPP or equivalent, to meet transportation package requirements (TRAMPAC), and to develop the technology required to produce IEB reliably and on the scale necessary to retrieve, process, and ship the RWMC waste to the permanent repository within the desired time frame. This work should include studies on 1) the retention and dissolution of TRU oxides in the IEB slag in solid solution with zirconia or equivalent, 2) the disposition during processing of the high vapor pressure metals including $\mathrm{Cs}, \mathrm{Pb}$, and $\mathrm{Hg}$, and 3) the controlled cooling process necessary to obtain the appropriate fine-grained crystalline structure necessary for minimum leaching of radionuclides and toxic substances. In addition, processing with plasma-jet and/or arc-heated melters 
should be initiated to attempt to overcome corrosion problems associated with JHM and to determine at lab scale any major processing problems with plasma/arc heated melters. 


\section{FOREWORD}

This report has been prepared for the Waste Technology Department in the Buried Waste Integrated Demonstration Program's Thermal Processing Technologies Project utiliyzing funding from the DOE Office of Technology Development. The report provides a survey of research performed at INEL on various aspects of the dissolution of mixed waste in INEL soil, which yields an ironenriched basalt (IEB). Much of the slag formation was done elsewhere, with the exception of the Joule heated melter work which was done at INEL. Almost all of the materials characterization was performed or directed by personnel at INEL.

The authors would like to thank those researchers who compiled the IEB data a decade ago, and for making it available now.

The contributions to the report far exceed the list of authors. M. T. Taylor and B. L. Tracy contributed significantly to the separate Thermal Processing 'T'echnologies Bibliography that includes the IEB bibliography. S. O. Bates and J. R. Weidner provided valuable reviews of the report. A. D. Donaldson, J. E. Flinn, P. C. Kong, and R. L. Miller proved to be experienced reference sources with whom we discussed systems, processes, and waste forms.

This report was prepared for the Waste Technology Development Department of EG\&G

Idaho Inc. under contract to the U.S. Department of Energy Idaho Field Office, Office of Technology Development. Funding was provided under FY-91 Thermal Processing Technologies, Technical Task Plan, ID-0502-DT, 1991, and ID-040E-2D, 1992. 


\section{CONTENTS}

ABSTRACT $\ldots \ldots \ldots \ldots \ldots \ldots \ldots \ldots \ldots \ldots \ldots \ldots \ldots \ldots \ldots \ldots \ldots \ldots \ldots \ldots \ldots \ldots$

EXECUTIVE SUMMARY $\ldots \ldots \ldots \ldots \ldots \ldots \ldots \ldots \ldots \ldots \ldots \ldots \ldots$

FOREWORD $\ldots \ldots \ldots \ldots \ldots \ldots \ldots \ldots \ldots \ldots \ldots \ldots \ldots \ldots \ldots \ldots \ldots \ldots$

ACRONYMS $\ldots \ldots \ldots \ldots \ldots \ldots \ldots \ldots \ldots \ldots \ldots \ldots \ldots \ldots \ldots \ldots \ldots \ldots \ldots \ldots \ldots \ldots \ldots$

1. INTRODUCTION $\ldots \ldots \ldots \ldots \ldots \ldots \ldots \ldots \ldots \ldots \ldots \ldots \ldots \ldots \ldots$

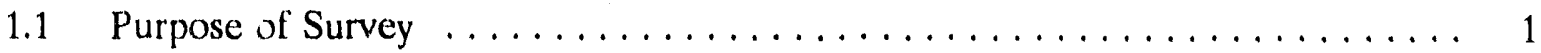

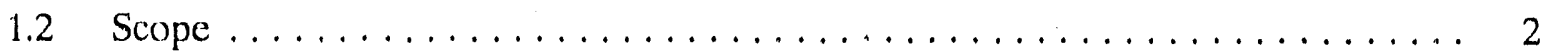

1.3 Background on IEB Development History $\ldots \ldots \ldots \ldots \ldots \ldots \ldots \ldots$

2. SUMMARY OF IEB WASTE FORM STUDIES TO DATE $\ldots \ldots \ldots \ldots \ldots \ldots$

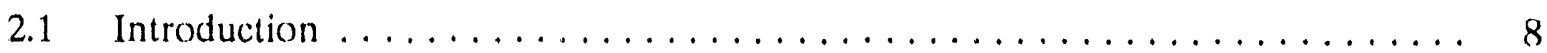

2.2 Melt/Slag and IEB Product Properties $\ldots \ldots \ldots \ldots \ldots \ldots \ldots \ldots$

2.2.1 Interaction of IEB with Refractories $\ldots \ldots \ldots \ldots \ldots \ldots \ldots \ldots \ldots$

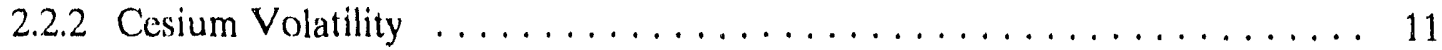

2.2 .3 Devitrification of IEB . . . . . . . . . . . . . . . . . . 11

2.2 .4 Behavior of Uranium and TRUs during Devitrification $\ldots \ldots \ldots \ldots \ldots 13$

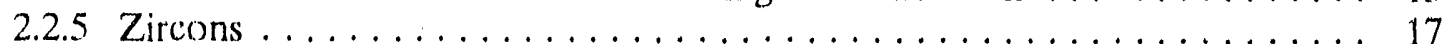

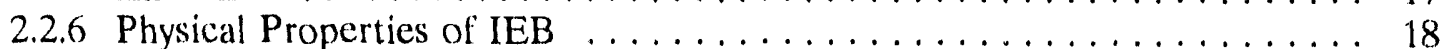

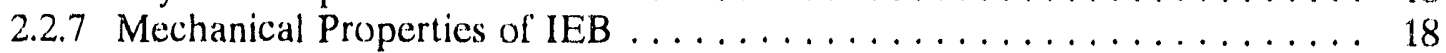

2.2 .8 Leaching Characteristics of IEB $\ldots \ldots \ldots \ldots \ldots \ldots \ldots \ldots \ldots \ldots \ldots$

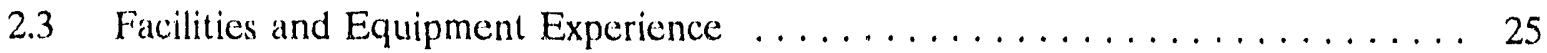

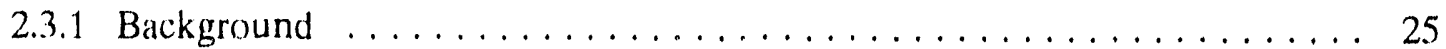

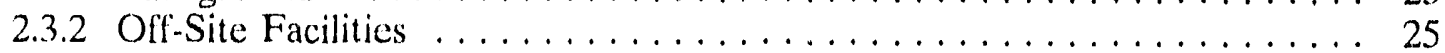

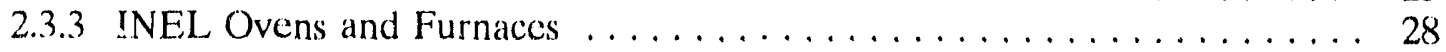

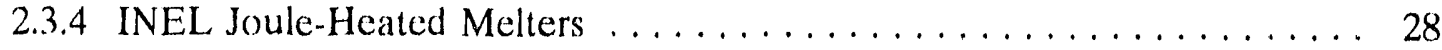

2.4 INEL JHM Operation $\ldots \ldots \ldots \ldots \ldots \ldots \ldots \ldots \ldots \ldots \ldots \ldots \ldots \ldots \ldots$

2.5 Equipment Design and Durability $\ldots \ldots \ldots \ldots \ldots \ldots \ldots \ldots \ldots \ldots$

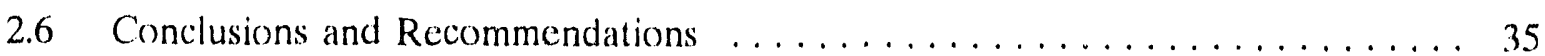

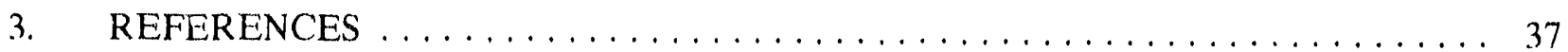

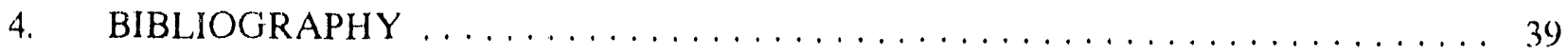

4.1 Introduction $\ldots \ldots \ldots \ldots \ldots \ldots \ldots \ldots \ldots \ldots \ldots \ldots \ldots \ldots$ 


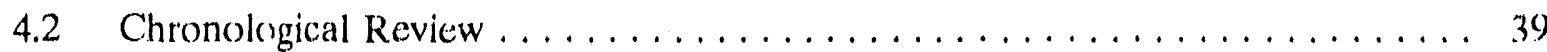

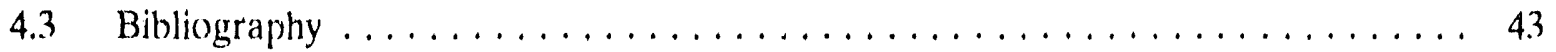

\section{FIGURES}

1. Variation of $A$ series slag constituents with soil additions $\ldots \ldots \ldots \ldots \ldots \ldots$

2. Tolerance Range of Major Oxides in Iron-Enriched Basalt $\ldots \ldots \ldots \ldots \ldots \ldots \ldots$

3. Correlation of corrosion rate of $90 \% \mathrm{Al}_{2} \mathrm{O}_{3}-10 \% \mathrm{Cr}_{2} \mathrm{O}_{3}$ refractory with the volume ratio

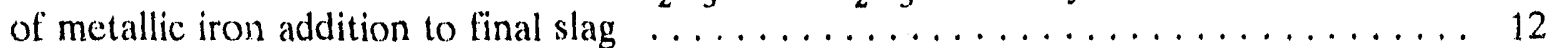

4. Temperature vs. Time for Devitrification of IEB $\ldots \ldots \ldots \ldots \ldots \ldots \ldots \ldots$

5. Photomicrographs $(500)$ X) of polished sections of A-0 and A-40 slags that underwent

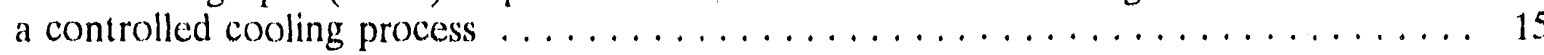

6. Viscosity as a function of reciprocal temperature for A-series slags . . . . . . . . i9

7. Electrical conductivity as a function of reciprocal temperature for the A-series slags . . 21

8. Specific heat capacity as a function of temperature for $\mathrm{A}-0$ composition slag with $\mathrm{Al}_{2} \mathrm{O}_{3}$

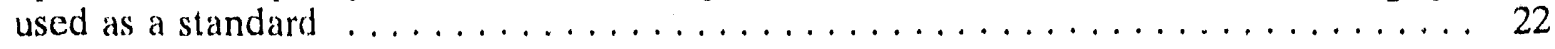

9. Actinide leach rates at 182 days as a function of temperature $\ldots \ldots \ldots \ldots \ldots$

10. INEL Joule-Heated Melting Furnace $\ldots \ldots \ldots \ldots \ldots \ldots \ldots \ldots \ldots \ldots \ldots \ldots$

\section{TABLES}

1. Comparison of Compositions of IEB and $\mathrm{BSG} \ldots \ldots \ldots \ldots \ldots \ldots \ldots \ldots \ldots$

2. Compositions (Major Oxide Components) of Selected Wastes, Soil

(without Volatiles), Nominal IEB, and Natural Basalt $\ldots \ldots \ldots \ldots \ldots \ldots \ldots \ldots$

3. Refractories tested in the slag-refractory interaction tests $\ldots \ldots \ldots \ldots \ldots \ldots \ldots$

4. Experimental viscosity and devitrification temperature results for A-series slags and with

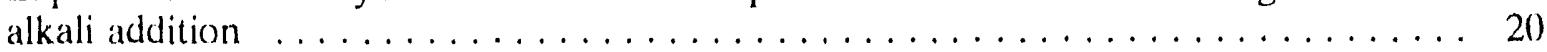

5. Comparison of uranium leach rates for a number of nuclear waste forms $\ldots \ldots \ldots$. . 27

6. Calculated compositions of nominal low-level transuranic waste slags produced in the Penberthy Electromelter . . . . . . . . . . . . . . . . 29

7. Composition of refractory brick used in the INEL electromelter $\ldots \ldots \ldots \ldots \ldots . \ldots 3$ 


\section{ACRONYMS}

CERCLA Comprehensive Environmental Response, Compensation, and Liability Act

CFR Code of Federal Regulations

DOE Department of Energy

EAF electric arc furnace

EDS energy-dispersive $x$-ray spectroscopy

EPA Environmental Protection Agency

HLW high-level waste

ICPP Idaho Chemical Processing Plant

IEB iron-enriched basalt

INEL Idaho National Fngineering Laboratory

ISV in situ vitrification

JHM Joule-heated melter

MAP mixed activation pluíuct

MFP mixed fission product

NRTS National Reactor Testing Station

PHM plasma-heated melter

RCRA Resource Conservation and Recovery Act

RFP Rocky Flats Plant

RWMC Radioactive Waste Management Complex

LLW low-level waste

SDA Subsurface Disposal Area

SEM scanning electron microscope

SPI slagging pyrolysis incinerator

TRA Test Reactor Area

TRU transuranic 
TSA

USBM

USGS

WIPP
Transuranic Storage Area

U. S. Bureau of Mines

U. S. Geological Survey

Waste Isolation Pilot Plant 


\title{
SUMMARY OF INEL RESEARCH ON THE IRON-ENRICHED BASALT WASTE FORM
}

\author{
THERMAL PROCESSING TECHNOLOGIES BURIED \\ WASTE INTEGRATED DEMONSTRATION PROGRAM
}

\section{INTRODUCTION}

\subsection{Purpose of Survey}

Presently, a high level of concern exists regarding the substantial quantities of hazardous, radioactive, and mixed TRU contaminated wastes currently in "temporary" storage and buried at the INEL. Because the INEL is not to be used as a permanent repository for such wastes, it will be necessary to retrieve, characterize, and process a wide variety of waste materials and associated contaminated soils in such a manner as to produce a stable waste form that is suitable for transport to a permanent repository and which will remain stable while permanently stored. In a 1978 report, Cox observed that

"There are no existing facilities capable of treating radioactive waste material on the scale necessary for the INEL facility."1

This statement remains true.

Between 8 million and 12 million $\mathrm{ft}^{3}\left(227,000\right.$ to $\left.340,000 \mathrm{~m}^{3}\right)$ of waste have been emplaced in the RWMC since it was opened in $1952,{ }^{2}$ and systematic records were not maintained until recently. The docus nentation of RWMC operations prior to 1970 was destroyed after the required retention period expired. ${ }^{3}$ The figures given for tie wastes do not include substantial quantities of overburden and underburden soils thai may be contaminated and require treatment.

The IEB glass/ceramic is a natural consequence of melting the mix of soil and waste compostion to be encountered at the RWMC. At present, the only waste form that is approved for permanent disposal of nuclear waste containing long lived radionuclides (e.g., $\mathrm{Pu}$ ) is BSG. Retricving INEL wastes and associated soils and converting this material to BSG would require large additions of $\mathrm{B}_{2} \mathrm{O}_{3}, \mathrm{Na}$, and glass frit $\left(\mathrm{SiO}_{2}\right)$ to convert the IEB composition to a $\mathrm{BSG}$ composition, even with the considerable overlap in compositional ranges. A comparison of the range of compositions of these two waste forms is shown in Table 1. In Table 2, a typical IEB recipe is shown for illustration with a typical BSE compostion. The INEL study showed that the IEB waste form performance can be at least as good, and possibly better than the approved BSG waste form. The purposes of this report are to review the INEL IEB data developed during 1979 to 1982, and to determine what extra 
Table 1. Comparison of Compositions of IEB and BSG.

\begin{tabular}{|c|c|c|c|}
\hline & \multicolumn{2}{|c|}{ Wt $\%$ Oxide } & \\
\hline & $\mathrm{IEB}^{\mathrm{a}}$ & $\mathrm{BSG}^{4}$ & \\
\hline $\mathrm{SiO}_{2}$ & $35-57$ & $25-50$ & \\
\hline $\mathrm{A}_{2} \mathrm{O}_{3}$ & $8-17$ & $0-10$ & \\
\hline $\mathrm{Fe}_{2} \mathrm{O}_{3}, \mathrm{Cr}_{2} \mathrm{O}_{3}, \mathrm{MnO}$ & $10-35$ & $1-20$ & \\
\hline $\mathrm{MgO}, \mathrm{CaO}$ & $0-18$ & $0-6$ & \\
\hline $\mathrm{Na}_{2} \mathrm{O}, \mathrm{K}_{2} \mathrm{O}, \mathrm{Li}_{2} \mathrm{O}$ & $0-7$ & $8-19$ & \\
\hline $\mathrm{ZrO}_{2}$ & $0-14$ & $-\cdots$ & \\
\hline $\mathrm{B}_{2} \mathrm{O}_{3}$ & $\cdots$ & $9-22$ & \\
\hline Fission Products & $\cdots$ & 30 & \\
\hline Actinides (including TRU) & $0->20$ & 1 & \\
\hline
\end{tabular}

a. Ranges estimated from Figure 2 .

effort may be needed to demonstrate that IEB is a suitable waste form forimmobilization of the TRU radionuclides encountered in wastes at the RWMC.

\subsection{Scope}

This report is part of a larger overall effort to develop and demonstrate thermal processing system options for the INEL buried mixed TRU wastes. As previously stated, this report reviews and summarizes the collection of publications, documents, and data pertaining to the 1979-82 IEB study conducted at INEL. The existing IEB knowledge base provides a starting point from which to assess the viability of the available thermal technologies for IEB production, and to determine what, if any, additional studies are needed to characterize and qualify IEB as an acceptable waste form for permanent storage of radioactive vastes.

The TRU waste form studies Annual Report was used as the basic guide for this study. ${ }^{5}$ Other documents published subsequently are less comprehensive but are referenced when appropriate. Also, a number of Internal Reports were reviewed, but are cited as unpublished data. Frequently, data contained in the Internal Reports were later published as Informal Reports, which were cleared for publication and cited when appropriate. Previously unpublished data on lab melter performance were also retrieved from archives, laboratory notebooks, and a manuscript. These were reviewed briefly, but detailed consideration of this material was beyond the scope of this initial study. The 
references listed in Section 3 refer only to those documents reviewed and cited for this review. A waste form bibliography is contained in Section 4.

\subsection{Background on IEB Development History}

Natural bas?al is a fine-grained, dark-colored extrusive igneous rock composed primarily of calcic plagioclase and pyroxene. Natural basalt is very resistant to weathering (or leaching) and is mechanically durable, so it seemed logical that a manufactured waste form of similar composition would be similarly leach-resistant and durable. Natural basalts have been melted and transformed into stable glasses and ceramics that exhibit chemical durability, high mechanical strength, and strong resistance to abrasion. ${ }^{6}$ The range of compositions encountered in natural basalts ${ }^{7}$ is shown in Table 2. In the table, A-0 stands for "average TRU waste" with $0 \%$ soil, A-40 is $40 \mathrm{wt} \%$ as soil, 60 wt \% as waste, and A-100 is $100 \mathrm{wt} \%$ soil. B-0 represents Rocky Flats sludges (as described later) with no soil. C-0 stands for the ash and metal container remains after treatment of combustibles by incineration. As the table indicates, except for a higher iron and a slightly lower alumina content, the composition of IEB fits easily into the compositional range given for natural basalts.

Most of the INEL soil cover is the wind-blown type (loess); however, the soil composition in some areas is dominated by weathering of adjacent topography and transport of these sediments onto the INEL by drainage systems. The soil chemistry at the RWMC is strongly influenced by decomposed rhyolite from adjacent Big Southern Butte and by sediments deposited in old stream channels of the Big Lost River. The RWMC soils are generally richer in clays and other materials that exhibit cation exchange capacity (CEC), meaning that they are able to capture and retain metal cations by the process of sorption and ion exchange. Sorption involves the adhesion of molecules :o the surfaces of a clay-rich minerals that carry an excess of negative charges, while ion exchange occurs due to displacement of ions on the mineral surface by ions in an aqueous solution. ${ }^{8}$ These capabilities plus the thickness of the soil cover and the low permeability of clay-dominated soils were major factors in siting the RWMC at a location where downward migration of metallic ions toward the aquifer was most likely to be inhibited. The clay-rich RWMC soils, when mixed with the waste, will produce IEB.

The RWMC is a temporary repository for transuranic (TRU) wastes at the INEL. Between 1952 and 1970, boxes and drums of waste were simply buried in pits and trenches and covered with soil. The size of the RWMC was increased several times until it covered 144 acres, and when expansion beyond this size was not permitted, trenches and pits were excavated to greater depths, to the underlying basalt in some cases, which negated the advantages of the low permeability and the CEC of the undisturbed soils. After 1970, the containers of waste were stacked on asphalt pads and covered with soil, and since 1976, some of the wastes have been stored beneath an air-suppcrted canopy, which permits operations to proceed regardless of the weather.

The TRU wastes are heterogeneous and include wood, paper, cloth, plastics, concrete, metals, chemical sludges, and contaminated soil. These wastes were loaded into steel drums and wooden or 
Table 2. Compositions (Major Oxide Components) of Selected Wastes, Soil (without Volatiles), Nominal IEB, ${ }^{5,9}$ and Natural Basalt. ${ }^{7}$

\begin{tabular}{|c|c|c|c|c|c|c|c|c|c|}
\hline \multicolumn{10}{|c|}{ Oxide Compounds (wt\%) } \\
\hline & $\mathrm{SiO}_{2}$ & $\mathrm{~A}_{2} \mathrm{O}_{3}$ & $\begin{array}{l}\mathrm{FeO}+ \\
\mathrm{Fe}_{2} \mathrm{O}_{3} \\
\end{array}$ & $\mathrm{CaO}$ & $\mathrm{MgO}$ & $\mathrm{Na}_{2} \mathrm{O}$ & $\mathrm{K}_{2} \mathrm{O}$ & $\mathrm{B}_{2} \mathrm{O}_{3}$ & Other \\
\hline A-O & 38.0 & 7.4 & 34.5 & 8.3 & 4.6 & 4.8 & 2.4 & $\cdots$ & 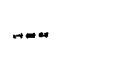 \\
\hline B-O & 42.6 & 4.3 & 19.1 & 14.1 & 7.8 & 9.4 & 2.6 & $\ldots$ & $\ldots$ \\
\hline $\mathrm{C}-\mathrm{O}$ & 2.8 & 1.8 & 91.3 & 3.5 & 0.5 & 0.03 & 0.1 & $\cdots$ & $\ldots$ \\
\hline $\begin{array}{l}\text { RWMC Soil } \\
(A-100)\end{array}$ & 65.4 & 12.5 & 4.8 & 9.6 & 2.5 & 1.5 & 2.9 & $\cdots$ & $\begin{array}{l}0.7 \\
\left(\mathrm{TiO}_{2}\right)\end{array}$ \\
\hline $\mathrm{BSG}^{\mathrm{a}}$ & 50.7 & 4.3 & 15.2 & 1.0 & 0.7 & 9.8 & $\begin{array}{c}5.2 \\
\left(\mathrm{Li}_{2} \mathrm{O}\right)\end{array}$ & 7.1 & 6.5 \\
\hline IEB $(A-40)$ & 51.0 & 10.3 & 19.6 & 9.7 & 3.5 & 3.2 & 2.6 & $-\cdots$ & $-\cdots$ \\
\hline Natural Basalt & $45-55$ & $13-17$ & $11-14$ & $7-10$ & $4-10$ & $2-4$ & $1-5$ & $\cdots$ & $\begin{array}{l}1-1.5 \\
\left(\mathrm{TiO}_{2}\right)\end{array}$ \\
\hline
\end{tabular}

cardboard boxes. Many of these containers were ruptured by heavy equipment when levelling the soil cover during pit closure, while others were breached due to simple deterioration during long-term burial. The variable composition of these wastes complicates conversion of TRU waste into a suitable waste form.

Several slag compositions were expected to result from the variety of RWMC wastes to be treated. The "Series" system was devised to describe these wastes: the "A-series" describes slag compositions that should result from mixing "Average" TRU waste, wastes that include sludges, combustibles, and noncombustibles (which includes any metals present) with RWMC soil. Because of the variable nature of such a mix the composition of average TRU waste cannot be precisely defined and a nominal composition was assigned for the purpose of the study. ${ }^{9}$ The "B-Series" slag is based on the composition of sludges, and the values for the composition were obtained from information provided by Rocky Flats on first- and second-stage sludges shipped to the RWMC during August 1970. ${ }^{9}$ The "C-Series" slag results from treating combustible wastes; assuming that all that remains after combustion is the ash residue and the metal container. The composition of RWMC soil was obtained by blending soil samples taken from several locations at the RWMC and having the oxide content of this composite sample determined by Mineral Research Center, Butte, MT, and by Pennsylvania State University. The results of these analyses were similar and were averaged for presentation in Table 2, along with the values used for the A-, B-, and C-Series slags. Most of the remainder of this report will be concerned only with the A-Series slags. The separation of the large metal content was not addressed in the original IEB work (1979-1982). 
If buried waste or waste that is stacked on a pad and covered with soil is to be retrieved and converted into a stable waste form, a variable amount of soil will accompany the waste and the composition of the final processed waste form will be influenced by the quantity and composition of this soil. The "A-0" in Table 2 describes the composition of average TRU waste only (no soil), while "A-100" describes the composition of $100 \%$ RWMC soil with no waste. The "A-40" composition, $60 \%$ waste and $40 \%$ soil, is given in Table 2. This ratio corresponds most closely to the composition defined as IEB. Figure 1 illustrates the variation of A-series slag constituents between the ratige of A- 0 and A-100, and Figure 2 shows the range of compositions that may be encountered in IEB, as well as the assigned values for the nominal IEB composition.

At present, in order to conserve the dwindling storage capacity at the RWMC, the Waste Experimental Reduction Facility (WERF) has developed capabilities to incinerate mostly-combustible waste and to melt and cast metals into ingots. Both the incineration and the melting processes are performed on sorted and characterized wastes and are used primarily for volume reduction. The incinerator ash is a mixed waste (toxic plus radioactive) and is blended with cement to produce a concrete wastc form. This approach is considered an interim solution for mixed waste disposal and a waiver enables WERF to treat incinerator ash in this manner. It is possible that this ash could be combined with retrieved RWMC waste and converted to IEB.

Experiments utilizing in situ vitrification (ISV) are underway to melt contaminated soil and buried waste in place, destroying the combustibles and immobilizing the noncombustibles in a large, leach-resistant block of glass. The ISV waste treatment concept is not yet considered a totally effective approach because the technology has not demonstrated "total containment" while processing RWMC-type waste in place. The chemistry of the ISV melts made at the INEL thus far are similar to IEB chemistry that would result from melting A-80 to A-100 rather than from the A-40 composition.

The IEB studies at the INEL showed that it is a very durable, versatile waste form with a broad range of potential applications. However, the INEL studies were terminated in 1982 based on a decision that the WIPP did not require the volume reduction and the durability afforded by this high technology waste form, and that BSG would serve the needs for immobilization of high-level waste. ${ }^{a}$ Incerest in IEB parallels ISV experiments at INEL on INEL buried waste with basaltic soil. Studies indicate that few alternatives are available that would enable retrieval and conversion of RWMC wastes and associated contaminated soils into a stable waste form for shipment to an offsite permanent storage location. Renewed interest in IEB warrants a review of the previous studies at the INEL to enable continuance of this work without wasting resources on unnecessary duplication.

a. Personal Communication with J. E. Flinn, June 1991. 


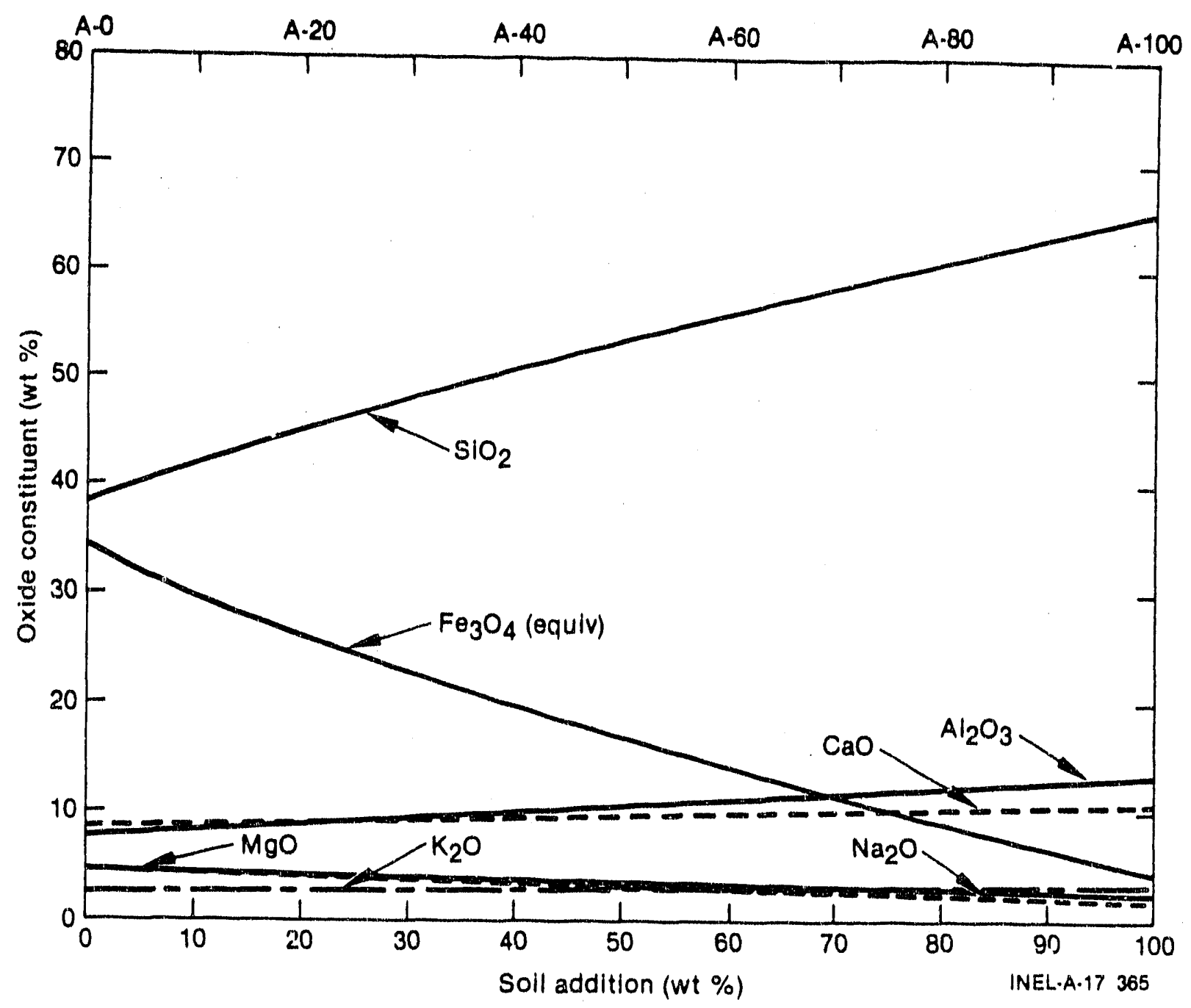

Figure 1. Variation of A-series slag constituents with soil additions. ${ }^{5}$ 


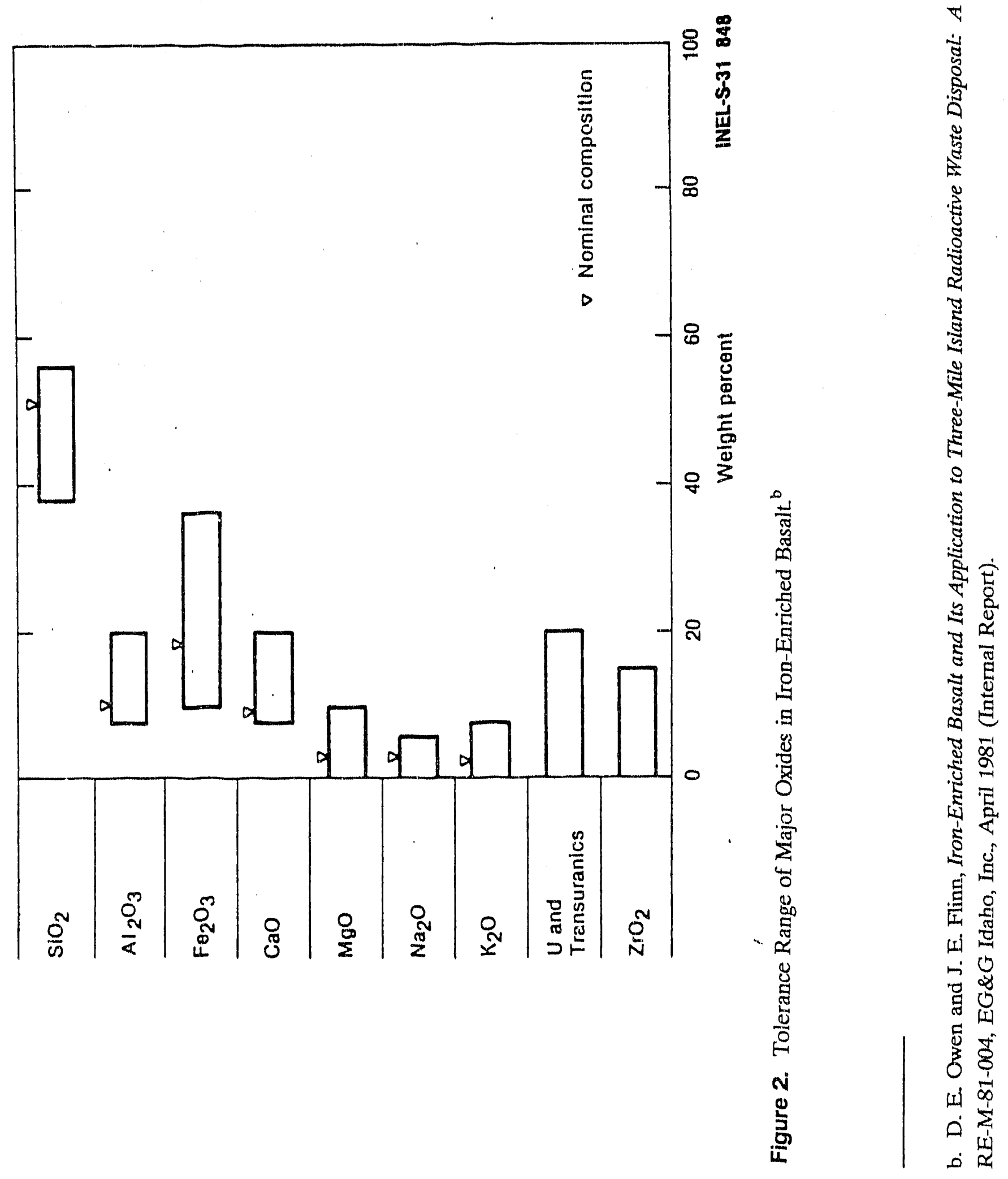




\section{SUMMARY OF IEB WASTE FORM STUDIES TO DATE}

\subsection{Introduction}

This section reviews the results obtained during the 1979-1982 INEL study of IEB. Interest in IEB as a waste form developed as a consequence of investigating the applicability of the slagging pyrolysis incinerator (SPI) for processing RWMC wastes. While this incinerator concept did not appear applicable to this problem, the endproduct that would have resulted from incineration of this waste exhibited some very desirable characteristics. This aspect was pursued and evolved into the IEB waste form.

Developing the technology to produce the IEB waste form requires a parametral study of the interaction of IEB with the equipment required for its production in addition to a determination of its performance as a waste form in its proposed permanent storage environment. Performance comparisons with BSG are necessary because BSG is the only approved waste form for permanent repository storage of nuclear wastes contaminated with long lived radionculides (e.g., Pu). BSG is approved for high-level nuclear waste. There is presently no approved final waste form or disposal option for buried or low-level stored TRU contaminated wastes. If the performance of IEB is equal to or better than that of BSG relative to the TRU contaminants of concern, it is presumed that IEB would be a strong candidate for approval as a low-level, TRU final waste form.

The various characteristics of IEB and the experience in its production in a lab-scale Jouleheated melier (JHM) are summarized in the following subsections.

\subsection{Melt/Slag and IEB Product Properties}

The nominal production temperature for IEB is $1500^{\circ} \mathrm{C}$, although the nominal IEB composition has been poured at $1350^{\circ} \mathrm{C}$, and batches at some extremes of the composition range (for example, low silica, high alkali - See Table 1) may pour satisfactorily at $1250^{\circ} \mathrm{C}$ or less. A satisfactory pour is achieved when the melt begins to flow readily when the furnace is tilted and will not accumulate in and block the pouring spout for the duration of the pour. A satisfactory pour does not necessarily produce a satisfactory casting.

BSG production in a JHM is done between 1050 and $1150^{\circ} \mathrm{C}^{4}$ and exceeding $1200^{\circ} \mathrm{C}$ is avoided. Increasing the temperature in a $\mathrm{BSG}$ unit to approach the minimum temperature used for IEB production would drastically reduce the furnace life and risk destruction of the Inconel 690 alloy electrodes. Further, BSG production for high-level waste uses a well-characterized, uniform feed that is the well-controlled output of a nuclear fuel reprocessing operation. Introducing a heterogeneous, unsorted, RWMC-type feed containing scrap metal directly into a BSG production unit would result in a series of system upsets that could halt processing. The operating temperature of a BSG process unit will not melt or rapidly oxidize and dissolve ferrous scrap. 
The higher temperatures needed for IEB production require a more robust processing unit and electrodes capable of enduring a more severe heating environment. The higher operating temperatures should permit the use of a more heterogeneous feed than could be tolerated in a BSG melter, especially if an oxidizing atmosphere can be maintained over the melt when a feed rich in combustibles is encountered. Higher temperatures will melt the ferrous scrap and will accelerate oxidization of the molten metal so the oxides may be incorporated into the slag. However, the higher operating temperature will cause volatile compounds to evaporate more quickly from the melt, and a more versatile and effective system must be designed to treat the furnace offgas before it is discharged to the atmosphere. Also, a heterogenous feed will require continuous monitoring of content to ensure the melt chemistry and final waste form properties are within disposal specifications, once they are defined.

Difficulties that may be encountered during production melting of IEB are numerous, even when operating within the recommended parameters. Free metals fall to the bottom of the melter until oxidized and dissolved into the slag. Adding a cold charge that chills the bath, or simply allowing the bath temperature to drop when "idling" the furnace, may result in crystallization of a high-melting temperature phase such as a spinel or $\mathrm{Fe}_{3} \mathrm{O}_{4}$. These crystals are denser than the melt and may settle to the bottom of the furnace as a cumulate or sludge. Because the bottom of the furnace is normally cooler, this cumulate would be difficult to redissolve and may impede $\mathrm{O}_{2}$ transport from the surface required to enable oxidation of a metal layer beneath the cumulate layer.

Low viscosity and/or low-melting components may tend to penetrate the refractories, or cracks and joints in the refractories, and accelerate refractory solution. A high viscosity composition would be difficult to pour and may not form a uniform monolithic waste form after pouring. The conductivity of the bath must also be controlled because high conductivity requires excessive current and taxes the power supply, while low conductivity requires a high voltage to maintain the desired current flow and may result in excessive current flowing through and heating the refractories. ${ }^{10}$ The INEL investigations included laboratory studies of the conductivities of various melt compositions but not conductivities of the several candidate refractories at temperatures that may be encountered during operation.

\subsubsection{Interaction of IEB with Refractories}

Most of the quantitative work in this area was done using refractory brick samples of the various compositions of interest. A container was made from a brick by using a diamond wheel to cut the brick into a $7.6 \times 7.6 \times 5.4 \mathrm{~cm}$ block and then using a diamond core drill to cut out a cylindrical cavity $2.6 \mathrm{~cm}$ dia. $\times 3.8 \mathrm{~cm}$ deep. This configuration was used for all the static refractory tests. The refractories tested are listed in Table 3, with the additional details of the tests discussed elscwhere. 5 
Table 3. Refractories tested in the slag-refractory interaction tests. ${ }^{5}$

\begin{tabular}{|c|c|c|}
\hline Remmy A-1 & & Pressed and Sintered SiC grains $(85 \%)$ with ceramic binder \\
\hline Remmy $Z^{a}$ & - & Pressed and sintered $\mathrm{ZrO}_{2}$ \\
\hline 99-AD & - & (Sintered) $99 \% \mathrm{Al}_{2} \mathrm{O}_{3}$ \\
\hline B-98 & - & Sintered (burned) $98 \% \mathrm{MgO}$ \\
\hline Delta $1^{a}$ & - & Pressed and sintered $60 \% \mathrm{MgO}-40 \% \mathrm{Cr}_{2} \mathrm{O}_{3}$ \\
\hline Ruby ${ }^{b}$ & - & Pressed and sintered $90 \% \mathrm{Al}_{2} \mathrm{O}_{3}-10 \% \mathrm{Cr}_{2} \mathrm{O}_{3}$ \\
\hline
\end{tabular}

a. Trade name, A. P. Green Refractories Co., Mexico, Missouri.

b. Trade name, Harbison-Walker Refractory Co.

The cavities were filled with $60 \mathrm{~g}$ of A-0, A-20, A-40, and A-100 slag compositions, each of which was doped with 3 wt $\% \mathrm{U}_{3} \mathrm{O}_{8}$ and the tcst blocks were placed in a $1500^{\circ} \mathrm{C}$ furnace for 7 days. The test blocks were then sectioned and examined using optical, scanning electron microscope (SEM), and alpha radiography techniques to determine the effect of the slags on each refractory composition. The cor osion depths and reaction layer thicknesses were measured. Of the refractories tested, the Ruby refiactory was judged superior on the basis of these tests, showing no corrosion (except for the A-40 composition) and minimal reaction layers. This brick composition was then subjected to additional tests for 7,14, and 30 days with the same slag compositions as before. Some difficulties were encountered in interpreting the results of these extended tests due to slag foaming and some slag loss; however, some comparisons were possible. The A-0 slag was the most corrosive. Corrosion by the A-20 and A-40 slags reached 1.15 and $1.3 \mathrm{~mm}$, respectively, after 14 days and corrosion had not proceeded further in 30 days. Corrosion by the A. 0 composition had reached 2.85 $\mathrm{mm}$ at 30) days and corrosion appeared to be continuing. No selective migration of uranium was detected. When the alkali content of the slags was increased, no corrosion effects were noted until the alkali content exceeded $10 \mathrm{wt} \%$ and the corrosion rate increased dramatically when the alkali content exceeded 15 to $20 \%$. However, the $10 \%$ alkali addition did cause the slag to migrate further into the refractory, even if the corrosion rate did not increase measurably. A test series indicated that increased concentrations of iron in the slag caused increased corrosion of the Ruby brick. The iron 
was added as metal, which oxidized and entered the slag during the course of the experiments. It was possible to correlate the Ruby refractory corrosion rate to the volume ratio of metallic iron addition to the total slag, as shown in Figure 3. The effect of $\mathrm{CaF}_{2}$ was not measured in this test series.

\subsubsection{Cesium Volatility}

The normal melt temperature for IEB is approximately $400^{\circ} \mathrm{C}$ above the temperature used to produce BSG (1050)-1150 ${ }^{\circ} \mathrm{C}$ ), which raises concerns about large amounts of volatiles being evolved from hotter IEB melts and causing problems in the offgas treatment system. Cesium compounds are a major concern, but other volatiles such as $\mathrm{Cd}, \mathrm{Hg}, \mathrm{Pb}, \mathrm{Zn}$, etc., will be emitted when processing RWMC wastes and a mixed waste will emerge as a product of whatever process is selected for treatment of the gaseous effluent that results from thermal treatment.

Cesiun-doped IEB melts were studied to determine cesium loss due to volatility, ${ }^{\text {c,11 }}$ These melts were done as scoping tests at 1300,1400 , and $1500^{\circ} \mathrm{C}$ in fireclay crucibles, and cesium loss was determined by comparing the chemistries of dip samples after 1, 2, and 4 hours exposures to the above temperatures to the quantity of $\mathrm{Cs}(4.31 \%)$ calculated to be in the original mix. No significant change in $\mathrm{Cs}$ content was detected in any of the samples, leading to the conclusion that there was

"no indication that melting temperature or hold time at that temperature affected the amount of cesium volatilized."c

This conclusion is not persuasive and the experiment should be repeated, analyzing the condensate on a cold finger instead of analyzing the melt, and using a typical BSG melt for comparison.

\subsubsection{Devitrification of IEB}

Devitrification of IEB entails conversion of the vitreous, obsidian-like form of IEB to a mixture of crystals and a residual glass phase. Obsidian is the glassy form of natural basalt and rhyolites that results when the melt is cooled too quickly to enable the crystalline phases to nucleate and grow. Improved physical properties and leach resistance may be obtained from devitrified IEB, especially if the elements that must be immobilized by the waste form can be incorporated into a more desirable crystalline phase. It is possible for some waste components to segregate into a less desirable phase. A finer-grained devitrified structure may be obtained if the casting is cooled to generate a large number of nuclei (nucleation step), and then the temperature is elevated to cnable these grains to grow. Elevating the temperature after the nucleation step enables diffusion to occur at an increased

c. R. M. Horton and J. M. Welch, Preliminary Assessment of Cesium Volatility from Iron-Enriched Basalt Melts, RE-M-81-(003, EG\&G Idaho, Inc., April 1981 (Internal Report). 


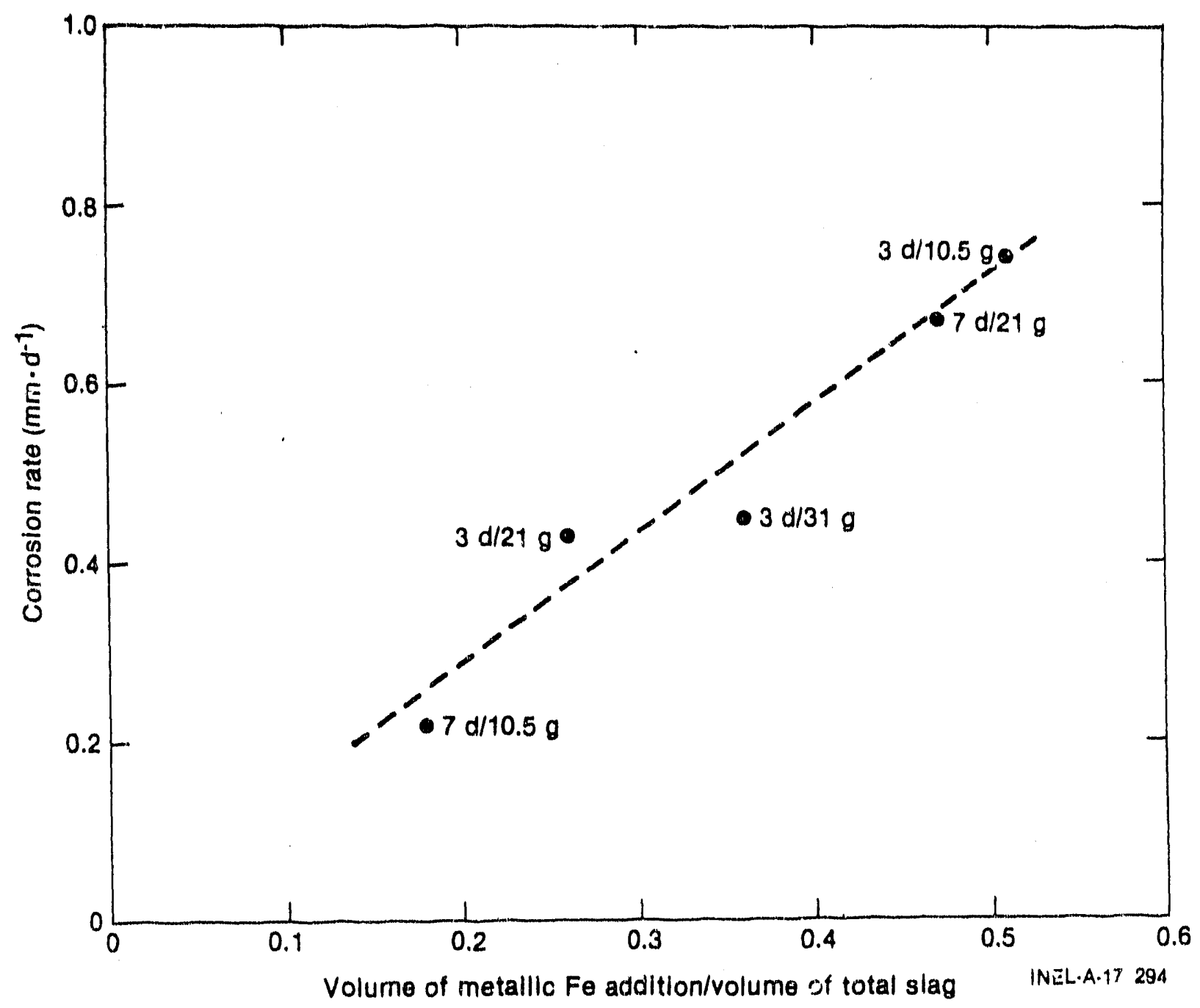

Figure 3. Correlation of corrosion rate of $90 \% \mathrm{Al}_{2} \mathrm{O}_{3}-10 \% \mathrm{Cr}_{2} \mathrm{O}_{3}$ refractory with the volume ratio of metallic iron addition to final slag. ${ }^{5}$ 
rate while the residual glass phase remains sufficiently plastic to accommodate stresses without fracturing. As the crystalline phases continue to grow, the composition of the remaining glass phase continues to change, reflecting a depletion of those elements that are incorporated into the growing crystals. Nucleation temperatures between 700 and $1000^{\circ} \mathrm{C}$ were tried but no clear relationship was detected between the nucleation temperature and the amount of residual glass remaining (as distinguished from the number and size of the crystals present), while temperatures above $1100^{\circ} \mathrm{C}$ were too high to achieve effective devitrification and caused some of the crystals to redissolve into the glass phase. A representative temperature vs. time plot for devitrification is shown in Figure 4, and the microstructures that result from this treatment are shown in Figure 5.

The presence of iron oxides, or more specifically, the ratio of $\mathrm{FeO}$ to $\mathrm{Fe}_{2} \mathrm{O}_{3}$ (or $\mathrm{Fe}^{+2}$ to $\mathrm{Fe}^{+3}$ ) determines the ease with which crystals may nucleate and grow from the glassy matrix. Beall and Rittler ${ }^{6}$ reported that the more oxidized basalts (those with lower $\mathrm{FeO}: \mathrm{Fe}_{2} \mathrm{O}_{3}$ ratios), could be devitrified more easily, and the best combination of properties in basalt-glass ceramics was achieved when heating well-oxidized glasses $\left(\mathrm{FeO}: \mathrm{Fe}_{2} \mathrm{O}_{3}<1\right)$ for 4 hours at $650^{\circ} \mathrm{C}$ to develop nuclei and $1 \mathrm{~h}$ at $880^{\circ} \mathrm{C}$ to grow pyroxene [augite, or augitic pyroxene, $\mathrm{Ca}(\mathrm{Mg}, \mathrm{Fe}, \mathrm{Al})(\mathrm{Si}, \mathrm{Al})_{2} \mathrm{O}_{6}$ ] crystals on the magnetite nuclei. Compositional variations within the limits that define IEB will significantly alter the composition of crystalline phases that deveiop during devitrification, as well as the composition of the residual glass phase. Both the nucleation and the growth temperatures reported by Beall and Rittler are lower than those reported for the INEL work, but it is not clear whether this was attributed to compositional differences or the $\mathrm{FeO}: \mathrm{Fe}_{2} \mathrm{O}_{3}$ ratio.

When plagioclase (see Figure 5) and other feldspar crystals develop during devitrification they will incorporate alkali and alkali earth metals into their structure, removing these oxides from the remaining glassy phase, thereby resulting in increases of the $\mathrm{SiO}_{2}$ and $\mathrm{Al}_{2} \mathrm{O}_{3}$ concentrations. The residual glass will then approach an alumina silicate composition, making it less leachable than the original melt composition. The decrease in IEB leachability has been attributed to the development of crystals during devitrification, when in fact the test specimens contained between 55 and $70 \%$ residual glass that was high in silica and alumina, and which enclosed most of the crystals, shielding them from the leach solution. In a related PNL study, ${ }^{12}$ analyses of the residual glassy phase showed that the $\mathrm{SiO}_{2}+\mathrm{Al}_{2} \mathrm{O}_{3}$ increased from 59 to $90 \%$ while the alkaline and alkaline-earth metals decreased from 18 to $5 \%$ and $\mathrm{Fe}_{2} \mathrm{O}_{3}$ decreased from 14.6 to $4.5 \%$. Thus, it is likely that the improved leach resistance resulting from devitrification is attributable not only to the formation of the crystalline structure but also in part to the simultaneous development of a less leachable glass composition.

\subsubsection{Behavior of Uranium and TRUs during Devitrification}

Without the presence of compounds to form host crystals, the $\mathrm{UO}_{2}$ and $\mathrm{PuO}_{2}$ present in IEB will form distinct crystals in the glassy matrix. These crystals apparently develop independently from 


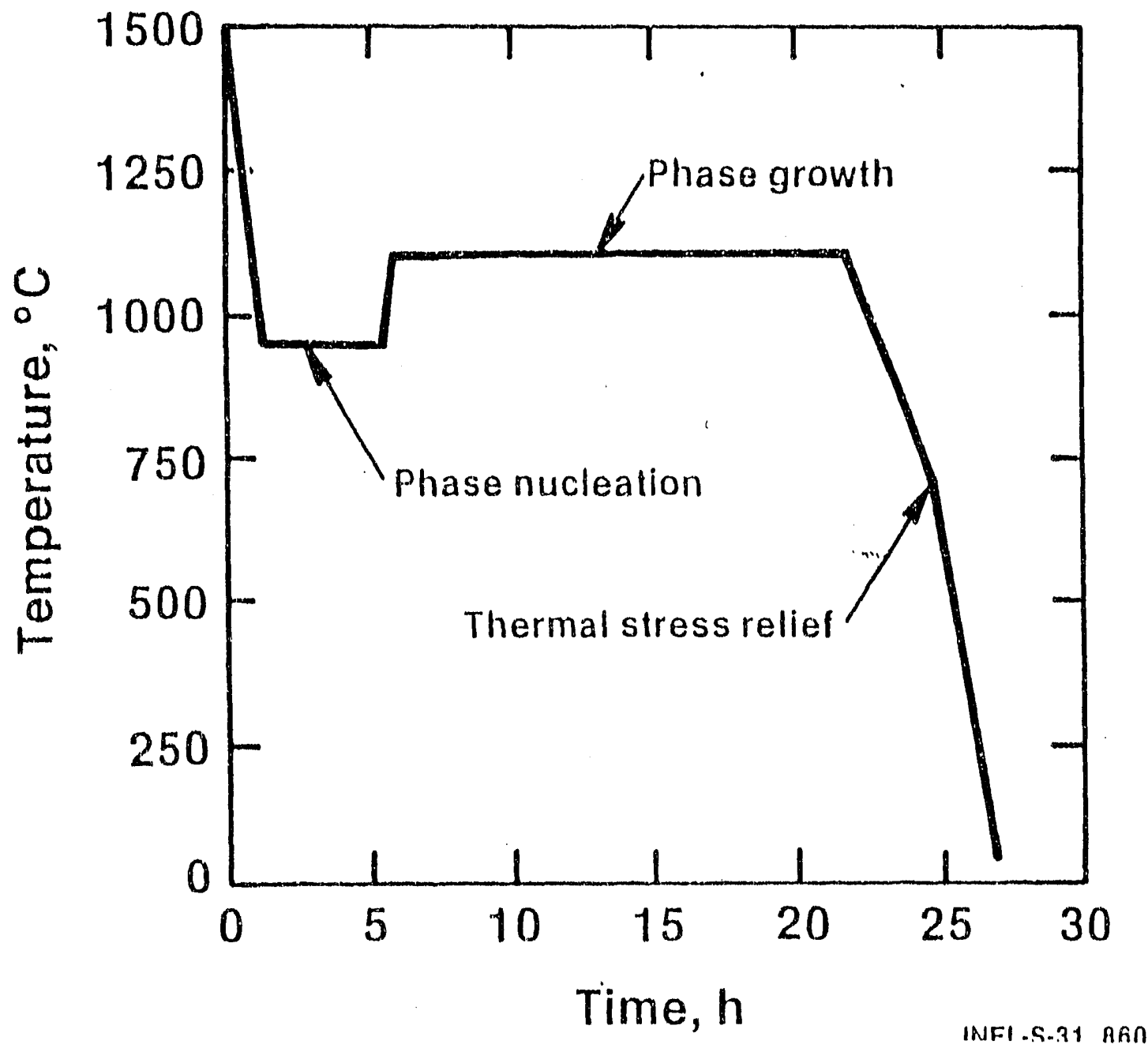

Figure 4. Temperature vs. Time for devitrification of IEB. 


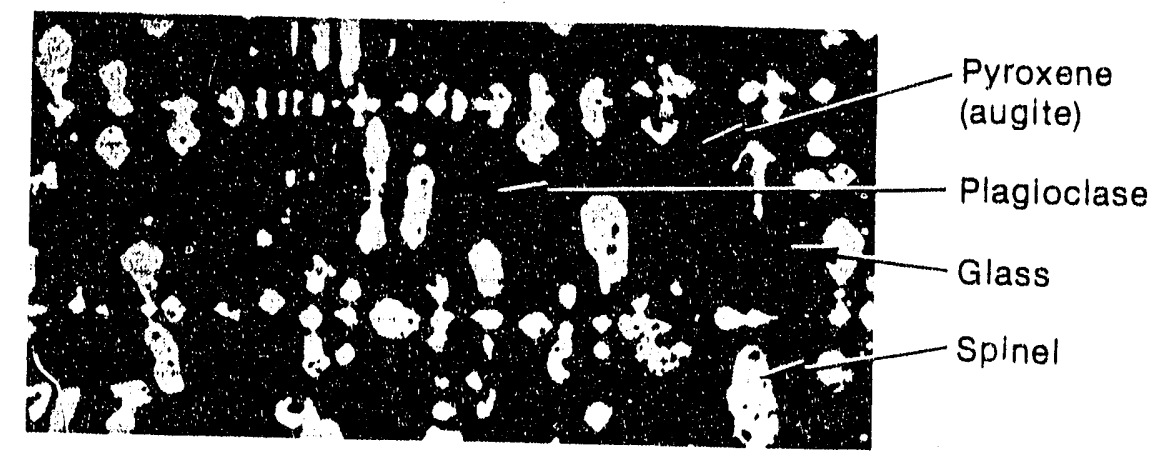

a.

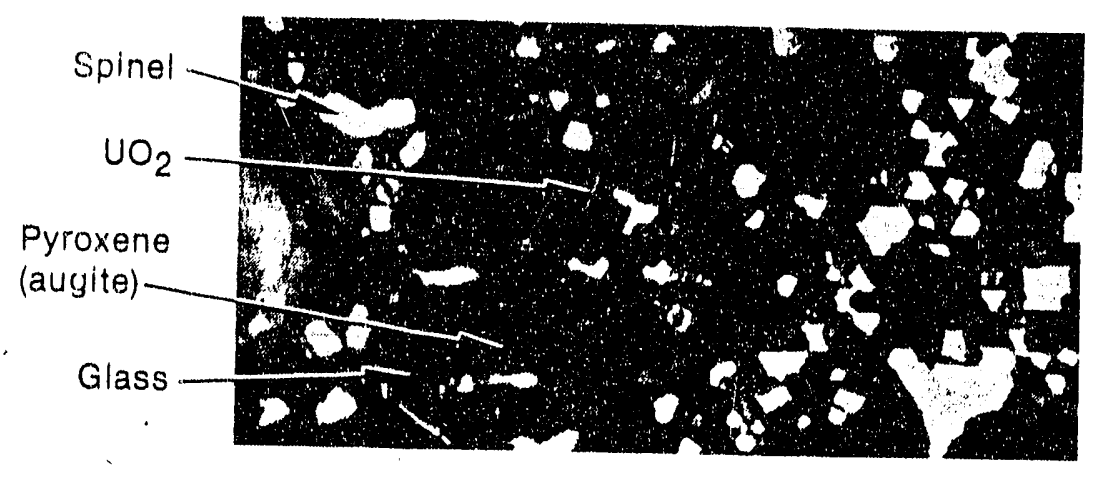

b.

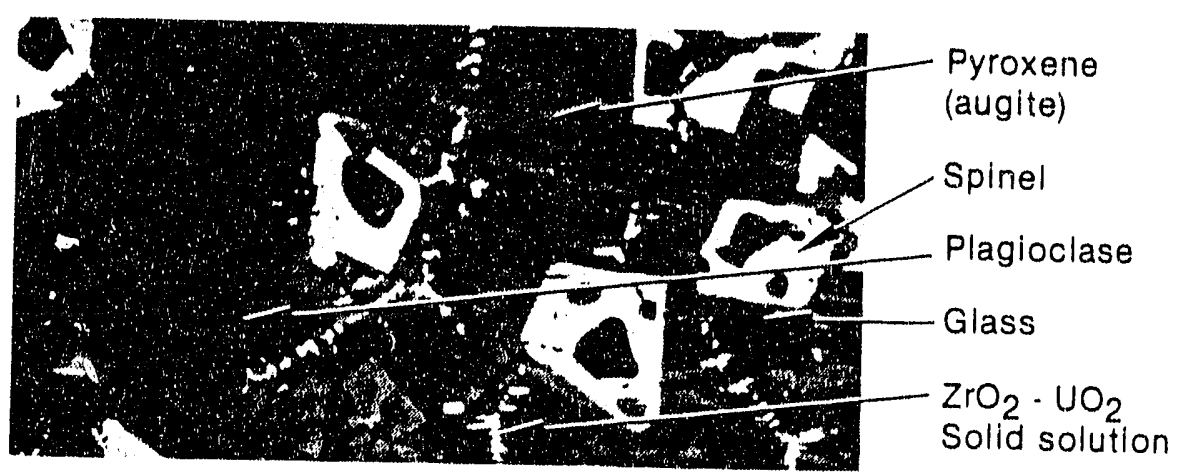

c.

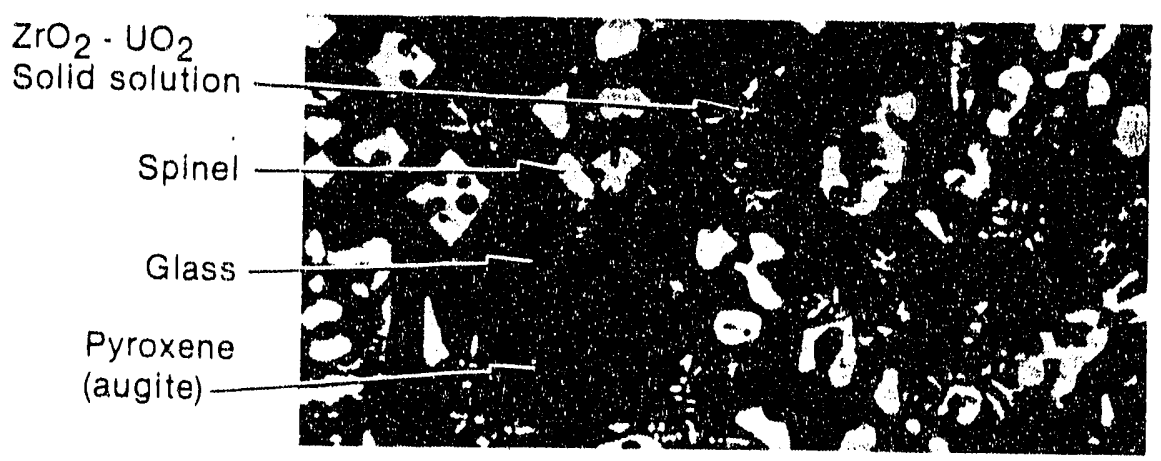

d.

Figure 5. Photomicrographs $(50() \mathrm{X})$ of polished sections of $\mathrm{A}-()$ and $\mathrm{A}-40$ slags that underwent a controlled cooling process: (a) A-O no $\mathrm{ZrO}_{2}$, (b) $2.5 \% \mathrm{ZrO}_{2}$, (c) $\mathrm{A}-\mathrm{O} 5 \% \mathrm{ZrO}_{2}$, (d) $\mathrm{A}-\mathrm{O} 10 \% \mathrm{ZrO}$, (c) A-40 no $\mathrm{ZrO}_{2}$, (l) A-40 $2.5 \% \mathrm{ZrO}_{2}$, (g) A-40 $5 \% \mathrm{ZrO}_{2}$, (h) A-40 $10 \% \mathrm{ZrO}_{2}$. 


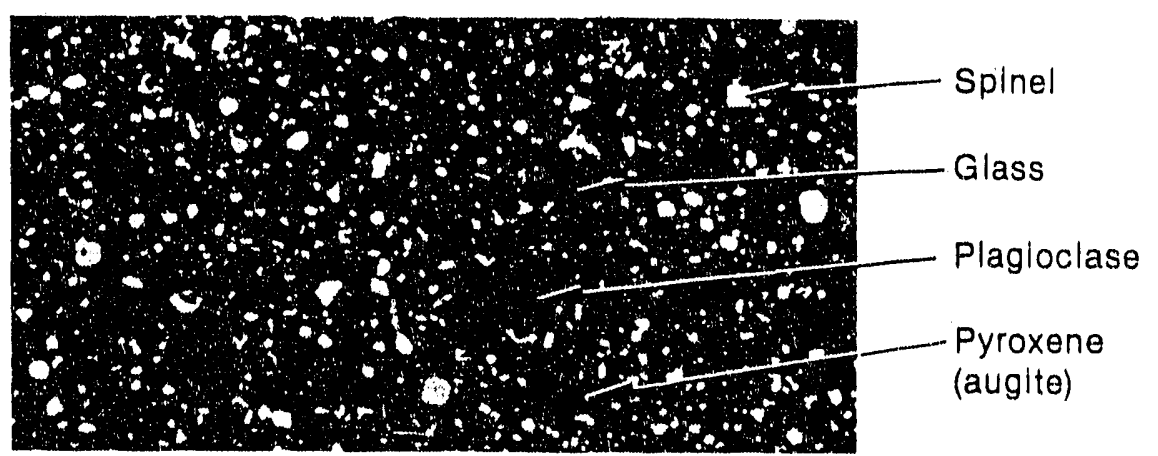

e.

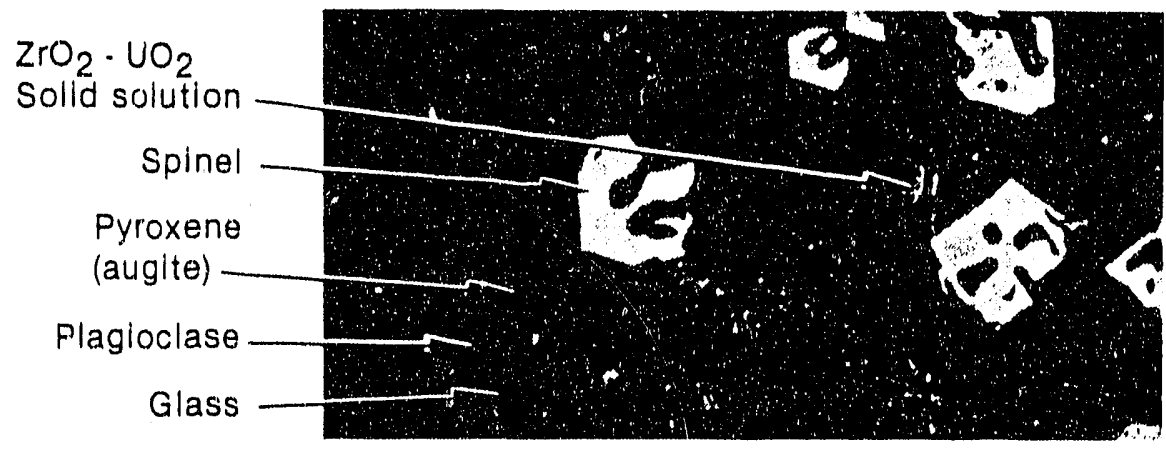

f.

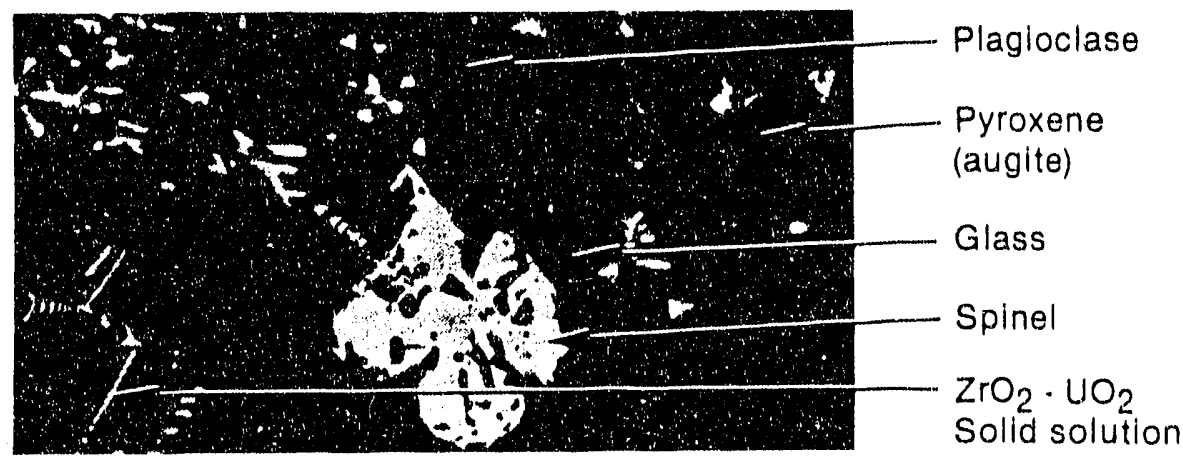

$\mathrm{g}$.

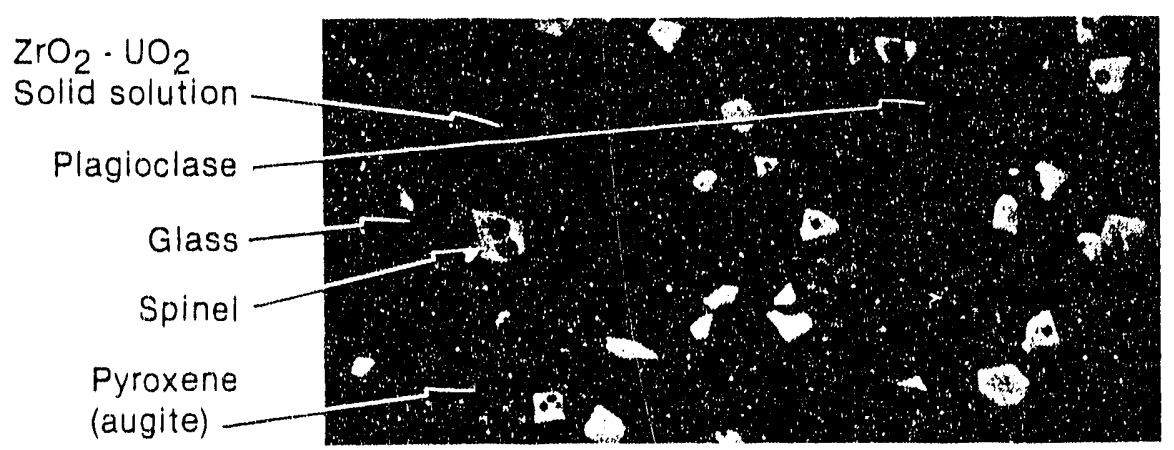

h.

Figure 5. (continued) 
the magnetite, spinel, augite, and feldspar that result from controlled cooling (see Figure 5). Other TRUs are expected to behave in a similar manner. The addition of $\mathrm{ZrO}_{2}$ to IEB will enable precipitation of $\mathrm{ZrO}_{2}$ (baddeleyite) on cooling, which is able to incorporate $\mathrm{UO}_{2}$ into its structure, thereby depleting $\mathrm{UO}_{2}$ in the glass phase. Such a development should benefit the leach resistance of the waste form. However, the ability of $\mathrm{ZrO}_{2}$ crystals to scavenge the TRUs from the residual glass has not been demonstrated nor has a comparison been made of leachability of these radionuclides in or out of the host phase. In the case of BSG, its composition inhibits devitrification but this vitreous waste form should have similar $U$ and TRU oxide phases. The ability to develop a non-leachable crystalline host phase for TRU disposal would be an additional advantage of the IEB waste form.

Little $\mathrm{ZrO}_{2}$ will be encountered in the TRU waste, so when uranium or the TRUs are detected, it appears that $\mathrm{ZrO}_{2}$ should be added so that it is about $20 \%$ of the uranium content. In an IEB melt containing $4.2 \% \mathrm{ZrO}_{2}$ and $15.1 \% \mathrm{UO}_{2}$, only $0.8 \%$ urania remained in the residual glass phase after devitrification. ${ }^{13}$

No references have been found where it was demonstrated that transuranics may be incorporated into the $\mathrm{ZrO}_{2}$ structure in a manner similar to uranium, although it is suspected that they will because of their very similar chemistries. Additional information should be sought and/or experiments should be conducted to verify that TRUs may be incorporated into certain crystalline structures in a manner similar to urania. It is likely that $\mathrm{TiO}_{2}$ and $\mathrm{HfO}$ may be substituted for $\mathrm{ZrO}_{2}$, and that these oxides may have some unique properties enabling them to scavenge TRU elements from the residual glass phase and incorporate them into a crystalline phase. Some preliminary work that investigated IEB containing both $\mathrm{ZrO}_{2}$ and $\mathrm{TiO}_{2}$ disclosed that crystals of zirconolite $(\mathrm{Ca} \mathrm{Zr}$ $\mathrm{Ti}_{2} \mathrm{O}_{7}$ ) could be precipitated from the melt between 1200 and $1250^{\circ} \mathrm{C}$ and this compound showed potential as a host crystal for actinides. ${ }^{14}$ Various samples of INEL soil indicate $\mathrm{TiO}_{2}$ of 0.6 to 1.0 wt $\%$, which may be sufficient to form the desired crystalline phases. Additional studies are warranted on this modification to IEB.

Cesium is a large ion that does not incorporate readily into crystalline structures as do other alkali metals such as $\mathrm{Na}$ and $\mathrm{K}$, so the residual glass becomes richer in $\mathrm{Cs}$ as IEB devitrifies. In a devitrified IEB sample containing 4\% cesium, energy dispersive $x$-ray spectroscopy (EDS) analyses detected no $\mathrm{Cs}$ in any of the several crystalline phases present, but disclosed that the residual aluminosilicate glassy phase had become enriched in Cs. The degree of Cs enrichment in the glass was not indicated, ${ }^{11}$ but $\mathrm{Cs}$ would likely be less leachable if incorporated into a crystalline phase.

\subsubsection{Zircons}

Zircons $\left(\mathrm{SiZrO}_{4}\right)$ are ranked among the most stable minerals known. They are found frequently as accessory minerals in granite, and when granite has been decomposed by weathering (leaching) over a period of millions of years, zircons are one of the few minerals that remain. Zircons are the host crystal for the uranium and thorium contained in granites (and other magmas) ${ }^{15}$ and their 
durability would be a distinct advantage if such host crystals could be developed in the IEB waste form. The authors feel zircons should be more thoroughly researched to determine the requirements for developing such crystals in IEB.

\subsubsection{Physical Properties of IEB}

The viscosities of several A-Series slag compositions were measured. ${ }^{\mathrm{d}, 5}$ These data are summarized in Table 4 and plotted in Figure 6, where the viscosity values are given as a function of melt composition. The viscosity data were fitted to the experimental equation:

$v=A_{0}^{E / R T}$

where $v$ is viscosity (Pa-s), $A_{o}$ is a material constant, $E$ is the activation energy for viscous flow, $R$ is the gas constant, and $\mathrm{T}$ is the temperature in $\mathrm{K}$. Not only does viscosity decrease with increasing temperature, but also with increasing iron oxide and alkali content. For comparison, the results for NBS Standard No. 710 (soda-lime-silica glass) and Columbia River (CR) basalts are included. Note that the viscosity plots for 10 and $20 \%$ alkali additions are superimposed, indicating that melt fluidity is not increased by adding alkali beyond $10 \%$. The minimum alkali to achieve the maximum viscosity effect was not determined.

Devitrification (crystallization) temperatures for the A-Series slags are also given in Table 4. Elsewhere in reference 5, the crystallization range for the spinels is given as between 1300 and $1400^{\circ} \mathrm{C}$, while augitic pyroxene crystallizes between 1200 and $1300^{\circ} \mathrm{C}$. The crystallization temperature was found to be a function of the redox state ${ }^{6}$ as indicated by the $\mathrm{Fe}^{+2} / \mathrm{Fe}^{+3}$ ratio of the IEB. It is related also to the iron oxide/silica ratio, and therefore is initially dependent on the IEB composition. If the slag is cooled rapidly, crystals that would form at lower temperatures have insufficient time to develop. The typical order of formation, with decreasing temperature is: Pure oxides, spinels, pyroxenes, and feldspars. The electrical conductivity of A-Series slags was also determined as a function of composition and temperature. ${ }^{5}$ The results are presented in Figure 7.

The heat capacity of A-0 composition slag was determined over the temperature range 200 to $700^{\circ} \mathrm{C}$ as shown in Figure 8.

\subsubsection{Mechanical Properties of IEB}

Mechanical property measurements enable an assessment of the characteristics of IEB for the purposes of handling and transportation. The tests developed were fracture toughness, splitting tensile strength, vibration, microindentations with microhardness, and laboratory-scale impact. ${ }^{5}$ Tests

d. S. P. Henslee and W. C. Seymour, Viscosity Measurements on A-Series Slags, RE-M-80-013, EG\&G Idaho, Inc., September 1980 (Internal Report). 


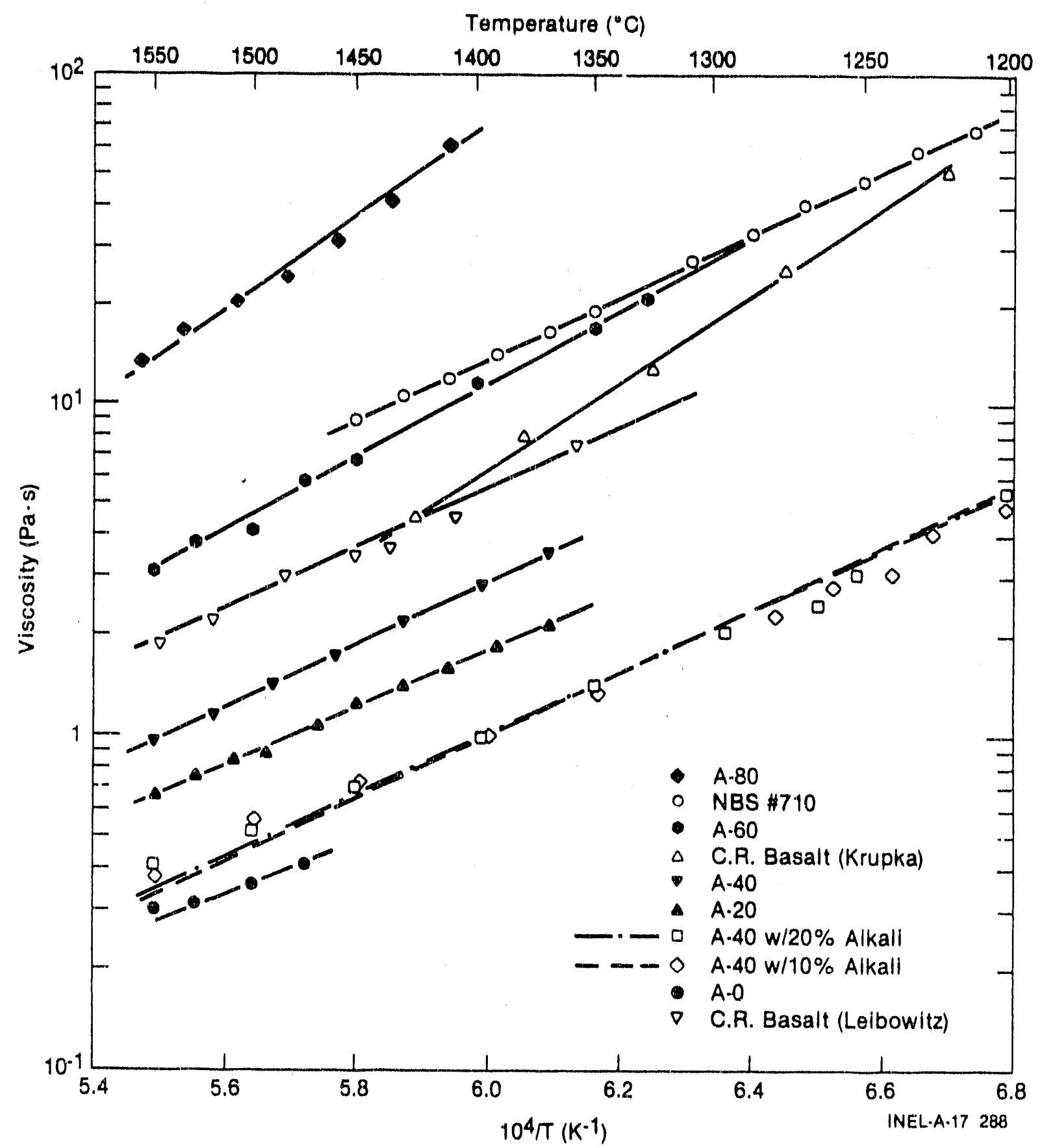

Figure 6. Viscosity as a function of reciprocal temperature for A-series slags. ${ }^{5}$ 
Table 4. Experimental viscosity and devitrification temperature results for A-series slags and with alkali addition. 5

\begin{tabular}{|c|c|c|c|c|}
\hline Specimen & $\begin{array}{c}A_{0} \\
(\mathrm{~Pa}-\mathrm{s})\end{array}$ & $\begin{array}{c}\mathrm{E} \\
\left(\mathrm{J} / \mathrm{g}-\mathrm{mole} \times 10^{4}\right)\end{array}$ & $\begin{array}{c}\text { Correlation } \\
\text { of Fit. }\end{array}$ & $\begin{array}{c}\text { Devitrification } \\
\text { Temperature } \\
\left({ }^{\circ} \mathrm{C}\right)\end{array}$ \\
\hline $\mathrm{A}-\mathrm{O}$ & $1.38 \times 10^{-4}$ & 11.59 & 0.96 & 1450 \\
\hline A- 20 & $1.12 \times 10^{-5}$ & 16.63 & 1.00 & 1350 \\
\hline A- 40 & $5.72 \times 10^{-6}$ & 18.21 & 1.00 & 1350 \\
\hline $\begin{array}{l}\text { A-40 } \\
\text { w/13\% alkali }\end{array}$ & $2.44 \times 10^{-6}$ & 17.88 & 1.00 & 1100 \\
\hline $\begin{array}{l}\text { A-40 } \\
w / 17 \% \text { alkali }\end{array}$ & $2.96 \times 10^{-6}$ & 17.65 & 0.994 & 1000 \\
\hline A- 60 & $2.43 \times 10^{-6}$ & 21.28 & 0.99 & 1275 \\
\hline A- 80 & $1.59 \times 10^{-6}$ & 24.28 & 0.99 & NA \\
\hline CR basalt $(2)^{16}$ & $6.3 \times 10^{-8}$ & 25.53 & 1.00 & NA \\
\hline CR basalt $(1)^{17}$ & $1.9 \times 10^{-5}$ & 17.50 & 0.97 & NA \\
\hline $\begin{array}{l}\text { Soda-lime-silica } \\
\text { glass (NBS Std 710) }\end{array}$ & $2.56 \times 10^{-5}$ & 18.29 & $1.00)$ & NA \\
\hline
\end{tabular}

were performed on A-series specimens and the results were compared to baseline data obtained on commercial high density alumina and borosilicate glass. This effort concentrated primarily on the development of the experimental techniques, and the mechanical property data obtained were not considered to be optimal, or even nominal, for the IEB waste form. At this stage of the work, data obtained on IEB samples for which processing was not carefully controlled should not be compared to data obtained on high quality specimens of alumina and pyrex glass.

Results from the tests indicate that the mechanical behavior of the A-series slag compositions did not appear to be influenced significantly by composition, except that the presence of $\mathrm{ZrO}_{2}$ crystals appeared to improve mechanical strength. 


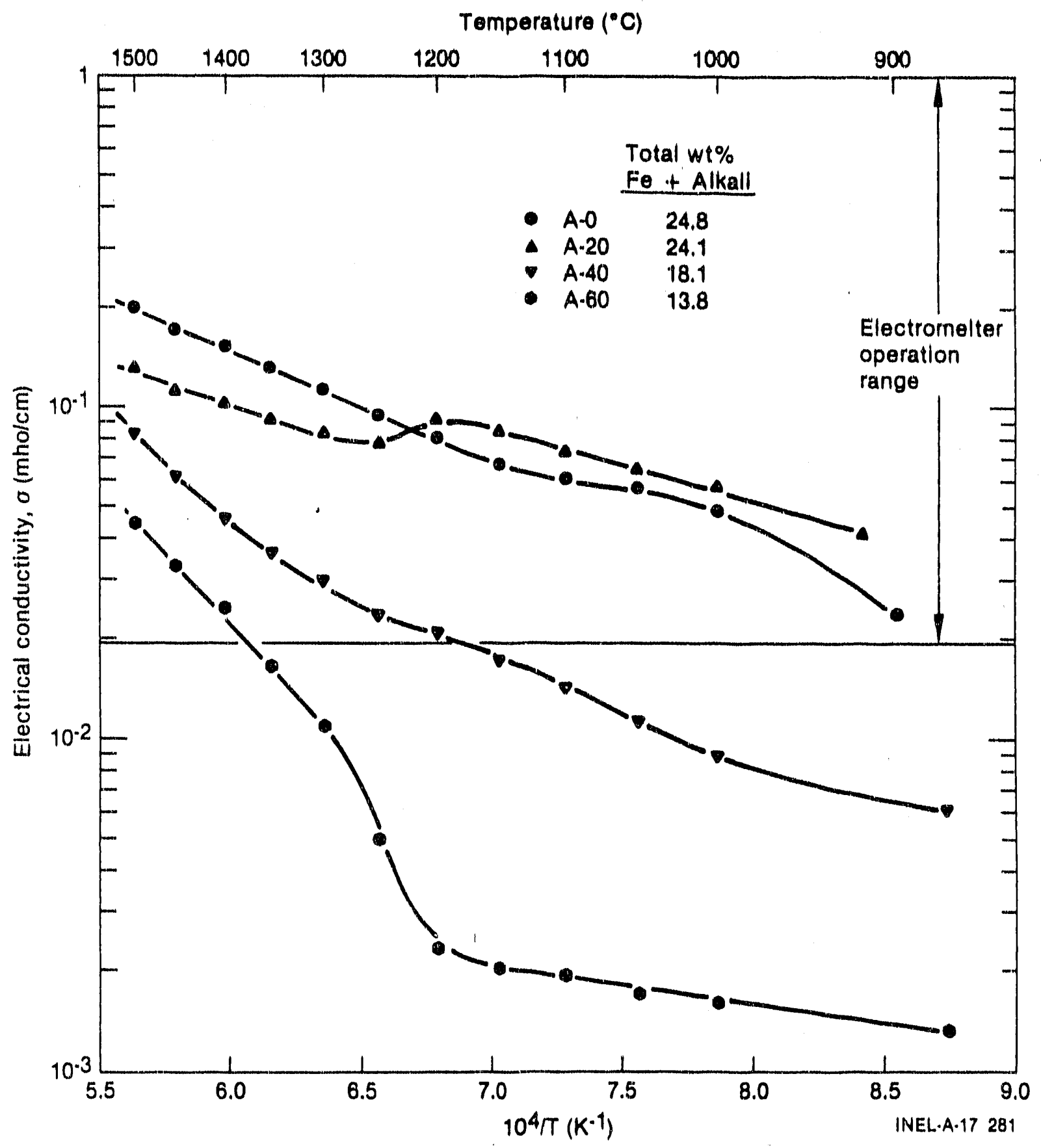

Figure 7. Electrical conductivity as a function of reciprocal temperature for the A-series slags. 


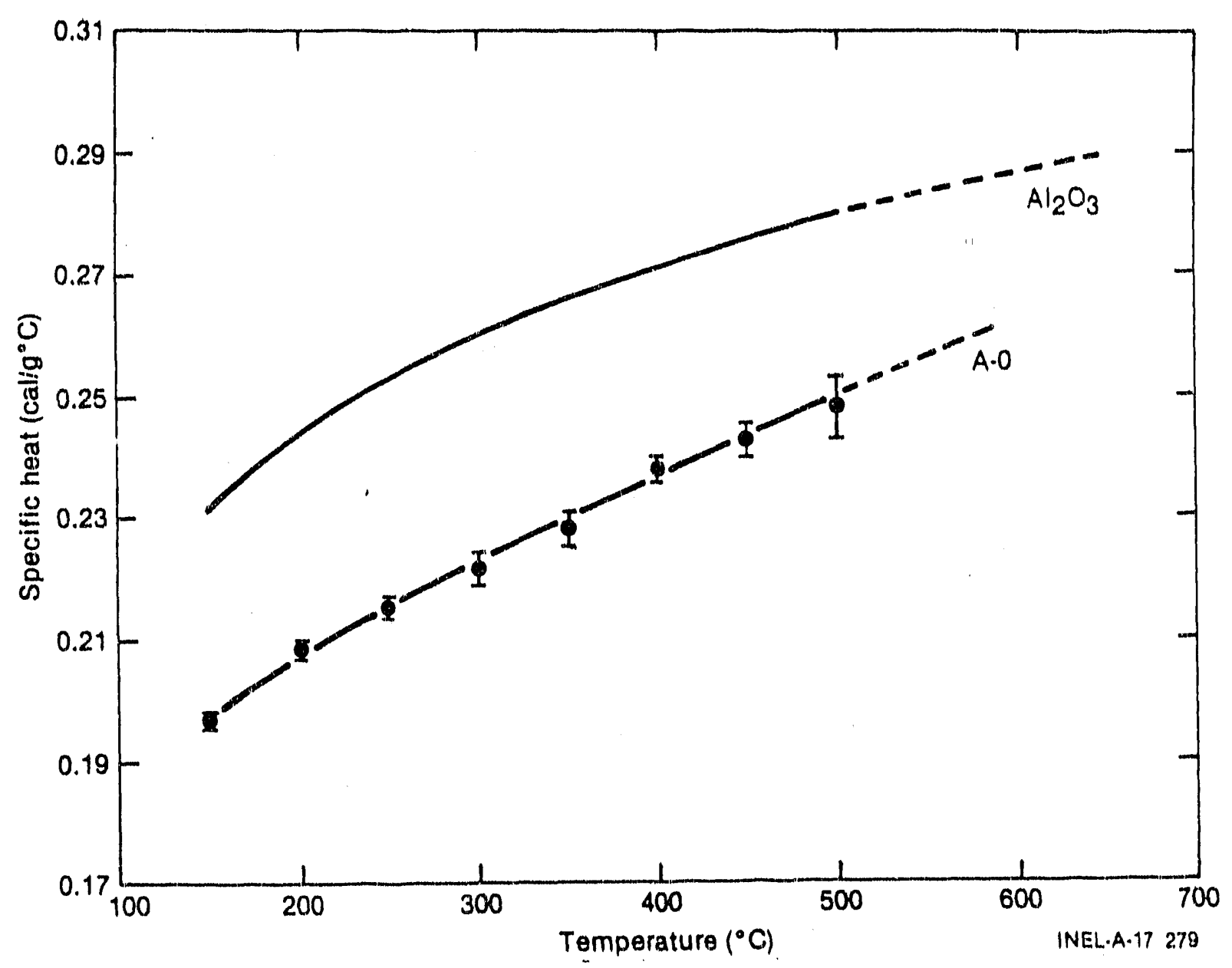

Figure 8. Specific heat capacity as a function of tempe ature for A-0 composition slag with $\mathrm{Al}_{2} \mathrm{O}_{3}$ used as a standard. 


\subsubsection{Leaching Characterlatlcs of IEB}

Leach tests determine the chemical durability of the IEB waste form. Leach testing constitutes a major effort for determining the suitability of a waste form for containment of radiolsotopes, and leach resistance is a major criterion for acceptability of a waste form. Static tests with delonized water at $90^{\circ} \mathrm{C}$ (MCC-1 Static Leach Test) ${ }^{18}$ were frequently used for leach test durations of up to 28 days, although some of the tests described used deionized water for lower lemperatures and longer times than suggested by MCC-1. Leachant change (semi-static), and Soxhlet test methods were also employed. Leach rates were estimated from specimen weight loss and from elemental analysis of the leachate. Some small-scale melts $\left(<100 \mathrm{~g}\right.$ ) were doped with $\mathrm{U}_{3} \mathrm{O}_{8}$, TRU elements, and fission products.

Material composition and structure were of major interest, with specific focus on iron oxide/silica ratios, effects of alkali content, and degree of devitrification. For the nominal A-series samples, no discernable influence on leach rate was attributable to compositional variations, (based on weight loss and leachate analyses), but the leach rates were so small that they approached the detection limit for the analytical equipment in use at that time. Doping with radioisotopes improves sensitivity. A large temperature dependence was noted in some static tests, and leach rates accelerated with increasing alkali metal content. Leach rates may become unacceptably high when alkali metal oxides exceed $10 \%$. Earlier it was observed that refractory corrosion becomes noticeable when the alkali content of melts exceeded $10 \%$ in the static tests.

Five IEB-related waste forms were doped with $1 \mu \mathrm{Ci} / \mathrm{g}$ each of ${ }^{237} \mathrm{~Np},{ }^{239} \mathrm{Pu},{ }^{241} \mathrm{Am}$, and ${ }^{244} \mathrm{Cm} .{ }^{19}$ The five waste forms were: Fritted IEB (molten IEB poured into water to form fragmented granules), IEB monolith, vitrifjed soil, vitrified Rocky Flats sludge, and fritted IEB as aggregate in Portland cement. Various samples were exposed to distilled water at temperatures between 25 and $9)^{\circ} \mathrm{C}$ for up to 364 days. Although a few small crystals were detected in the monolith, all of the samples were considered vitreous.

In all of the tests there was a general decrease of leach rate with time, probably due to saturation effects. The least amount of TRU was leached from the cemented frit. Cement is not rated as a durable waste form for permanent disposal; however, for the duration of this test series, the cement surrounding the frit particles restricted access of the leachate, and the strongly alkaline environment around the frit aggregate produced by the $\mathrm{CaO}$ in the cement developed hydroxides of the radioisotopes which inhibited their movement into the leachate. The leach rate lor the vitrified sludge was also intribited when the leachate had a high $\mathrm{pH}$. Of the actinides, ${ }^{237} \mathrm{~Np}$ had the highest leach rates, especially at higher temperatures (up $1090^{\circ} \mathrm{C}$ ). Plots of the actinide leach rates after 182 days are shown in Figure 9. These leach rates are for the primarily glassy form of IEB (not the crystalline form) and therefore represent a higher leach rate than expected from the more stable crystalline form. 


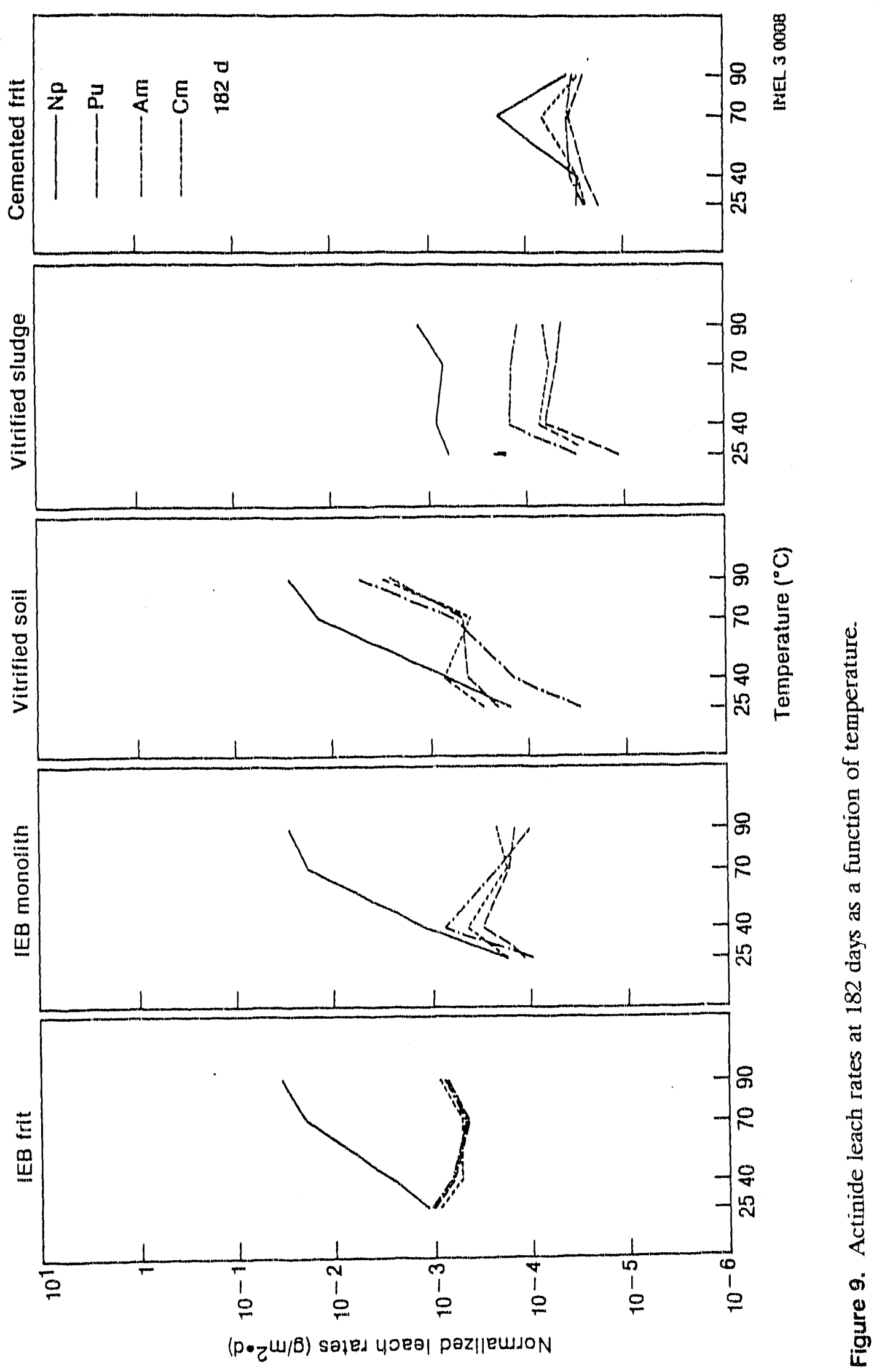


Comparisons of the leach rate of $\mathrm{Pu}$ from $\mathrm{BSG}^{12}$ with the leach rate of $\mathrm{Pu}$ from the vitreous IEB monolith at $90^{\circ} \mathrm{C}$ for the standard 28 -day test perion yielded questionable results. ${ }^{18}$ Because the BSG tests were performed at PNL and the IEB tests were performed at the INEL, it is not possible presently to compare the BSG and IEB compositions, structures, Pu contents, potential saturation of the leachates, or other test conditions that might quantify the results. The vitreous IEB has been demonstrated to be more vulnerable to leaching than the devitrifted IEB. No leach tests involving $\mathrm{Pu}$ in devitrified IEB were found.

A comparison of the uranium leach rates from devitrified IEB and other waste forms in deionized water, brine, and silicate water is presented in Table 5. The results generally indicate superior performance from the ceramics (the IEBs, tailored ceramic, and Synroc) compared to the glasses (BSG and high-silica) with substantially higher uranium loading in the case of IEB. ${ }^{13}$ The results obtained with uranium tend to contradict the results obtained with plutonium. Another test series of devitrified IEB doped with ${ }^{2 A 1} \mathrm{Am}$ showed americium leach rates that are consistently lower than the weight loss leach rates. ${ }^{20}$

Additional leach testing of IEB would be useful, with emphasis on those compositions amenable to devitrification and to production of crystalline structures such as $\mathrm{ZrO}_{2}$ and/or $\mathrm{ZrSiO}_{4}$, which should be suitable as hosts for TRU elements. The standard 28 -day, $90^{\circ} \mathrm{C}$, deiorized leachant could be employed for screening, with brine and/or silicate leachants used for longer teim exposures of the most promising candidates.

\subsection{Facillties and Equipment Experlence}

\subsubsection{Background}

Most of the early work on IEB was done lab-scale using small melts that ranged betwein 50 and $500 \mathrm{~g}$. No equipment was available to produce melts of substantial size, so when : uch experiments were considered necessary, this work was contracted out until a JHM unit couk be placed in service at INEL to enable testing IEB production on a pilot-scale basis. As noted earlier, the product of the slagging pyrolysis incinerator initiated interest in the IEB waste form. The activitics with this unit and other facilities offsite are discussed in the next section. Subsequently, a pilot-scale JHM and a "miniature" JHM were operated at INEL and the experiences with these units are also summarized. Again, the cited INEL Annual Report (Reference 5) was used as a basis for this summary, although more reliance was placed on unpublished data.

\subsubsection{Off-Site Facilities}

The slagging pyrolysis incinerator (SPI) was devised primarily for treating municipal waste and was considered for treatment of RWMC waste because its capacity could be large enough $(200,000 \mathrm{~kg} / \mathrm{d})$ to treat $\mathrm{RWMC}$ waste on the scale necessary to complete the task within a reasonable time frame. ${ }^{1}$ Temperatures within the SPI could reach a maximum of $1650^{\circ} \mathrm{C}$ and the offgas could 
reach in excess of $1450^{\circ} \mathrm{C}$. These temperatures were significantly higher than those normally encountered when incinerating municipal waste. The requirement for supplemental fuel, if any, is dependent on the quantity of combustibles contained in the waste, while the byproducts are a basaltic slag and the offgas. The SPI did not work well on municipal waste unless the feed was lairly uniform. System upsets were frequent when variable feed compositions were used. The SPI was a shaft type furnace, which is inherently vulnerable to bridging in the descending column of waste and freezing of the bath due to "off-normal" operation caused by the variations in feed material. Such conditions usually must be corrected manually, which is often difficult and cannot be tolerated when melting the TRU and other wastes that require remote equipment operation.

Because of the nature of the RWMC waste and accompanying soil, the basaltic slag composition was of particular interest. Samples of SPI slag were obtained for study from a 64,060) $\mathrm{kg} / \mathrm{d}$ SPI unit that was opcrated by Andeo-Terrax to process municipal waste in the Buffalo, N.Y. area. The Andco-Terrax slag was quenched in water to produce a frit. Examination of samples of this frit disclosed that bits of charcoal and metal were trapped in a glassy phase resembling obsidian. The presence of the charcoal and metal indicated that this slag was produced in a strongly reducing rather than in an oxidizing environment.

Because experience with incineration of radioactive waste was lacking and few data were available regarding radionuclide behavior in a basaltic waste form, preliminary studies concentrated on interaction of this slag composition with refractories as well as its resistance to leaching. ${ }^{9}$ 'This work was done on fractional liter samples. No equipment was available at the INEL at this time to produce IEB on a pilot scale so work was subcontracted to the U.S. Burcau of Mines, Albany, OR, and to Penberthy Electromelt, Seattle, WA, to produce a number of heats of IEB in about $100 \mathrm{~kg}$ sizes to assess the feasibility of constructing a furnace with a similar capacity at the INEL.

Through an interagency agreement, the U. S. Bureau of Mines (USBM), conducted six melting tests using a one ton electric arc furnace at its Albany Research Center, in Albany, OR. The furnace was charged with simulated wastes that resembled the A-, B-, and C-series, and fluxes were added as necessary to produce basaltic slags, although typically a conventional electric are furnace is not expected to operate efficiently when used as an incinerator. ${ }^{21}$ When combustibles were charged, the furnace had to be led slrwly, especially when significant polyethylene waste was present, to avoid generation of excessive soot and fumes that would produce unstable furnace operation. While operation was not efficient and refractory wear and electrode consumption was excessive, the furnace was able to achieve $16(\%)^{\circ} \mathrm{C}$ and convert the various wastes into a basaltic slag that was poured into 208-L (55-gal) steel drums. Because of the difficulty in handling variable amounts of combustibles the USBM concluded that this was not a proper use for such an are furnace; however, based on their findings this process does appear to have merit for conversion of primarily non-combustible mixed wastes into the IEB waste form. Aciditional studies should be undertaken to determine if processing adjustments will enable productive use of the arc furnace as part of a complete waste treatment system. The are furnace used for the INEL tests has been replaced with another unit that should be suitable for additional studies if warranted. 


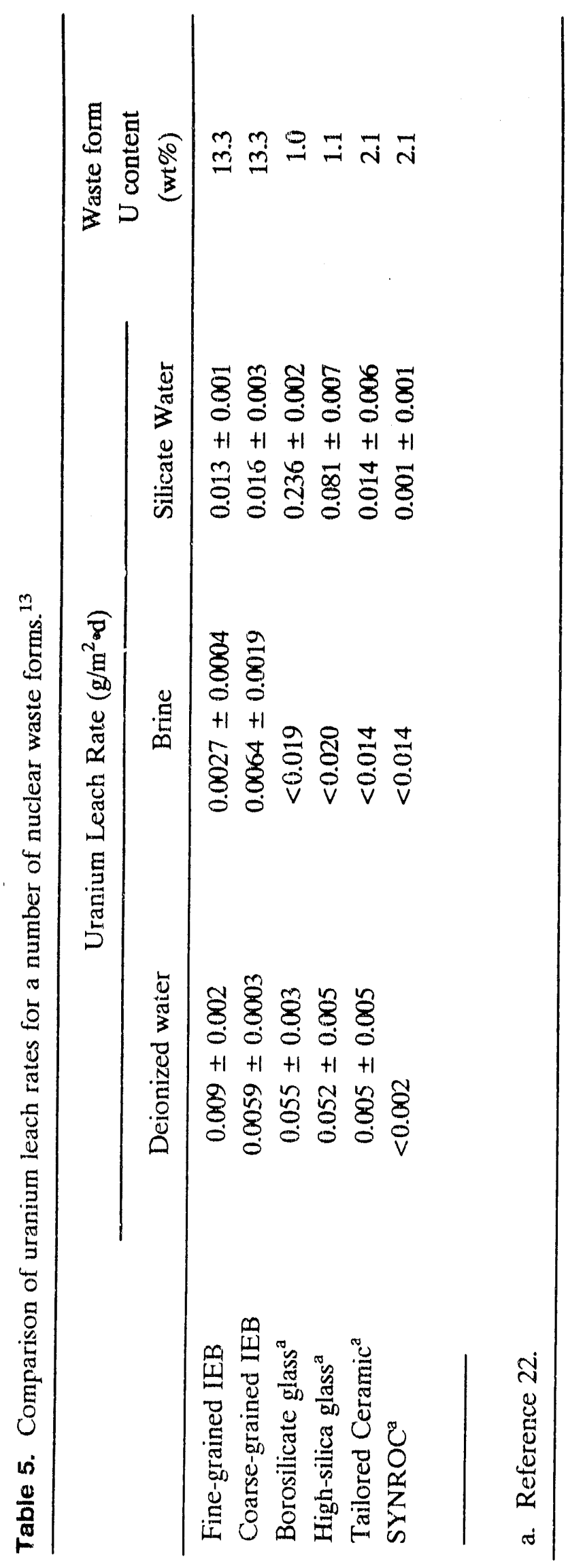


Seven castings averaging about $90 \mathrm{~kg}$ each, were produced by the Penberthy Electromelter (a JHM). These melts were made at 1410 to $1480^{\circ} \mathrm{C}$ and poured into thin-walled $(1.0$ to $2.0 \mathrm{~mm}$ ) steel drums. Thermocouples were present in the drums to monitor the temperature during pouring and cooldown. Some drums had a $3 \mathrm{~cm}$ layer of sand in the bottom, while another rested on a steel chill plate to prevent the hot slag from melting through the thin bottom of the drum. No melt-throughs were encountered. The estimated compositions of the heats are listed in Table 6.

Four of the containers were sectioned and the contents subjected to a variety of tests to determine the physical and chemical characteristics of IEB. The IEB castings fell out of the steel drums after sectioning and the interior drum surfaces were smooth and clean, indicating that no reaction occurred between the steel drum wall and the slag. The IEB produced in the Penberthy Electromelter provided ample material for study until the INEL joule heated melter could be placed into operation.

\subsubsection{INEL. Ovens and Furnaces}

Insufficient capital equipment funding precluded purchase of laboratory furnaces necessary to do the laboratory-scale melting work at the INEL. Because only relatively unsophisticated equipment was needed to accomplish most of these tasks, these units were constructed at the INEL using firebrick and castable refractories. High alumina refractories and molybdenum disilicide resistance elements enabled testing at temperatures to $1700^{\circ} \mathrm{C}$ if desired. Laboratory samples were melted in fireclay or sillimanite crucibles. Some crucibles were made from refractory brick to test the compatibility of refractories with various IEB compositions over a range of temperatures. The refractory brick crucibles were made using a diamond core drill to form the cylindrical cavity in the brick to contain the IEB meit.

\subsubsection{INEL Joule-Heated Melters}

In order to develop data for RWMC waste treatment at a pilot-scale facility, a joulc-heated melter (JHM) was designed and built so that data could be generated that were applicable for construction of pilot-scale and remotely-operated units if this concept proved to be applicable. A schematic of the INEL JHM is shown in Figure 10. This furnace was similar in principle to the Penberthy unit and produced IEB by melting noncombustible, simulated nuclear wastes. ${ }^{23}$ The unit made extensive use of castable refractories, although the melting chamber itself was lined with Harbison-Walker "Ruby" brick $\left(90 \% \mathrm{Al}_{2} \mathrm{O}_{3}-10 \% \mathrm{Cr}_{2} \mathrm{O}_{3}\right)$ that had demonstrated good resistance to penetration by IEB at elevated temperatures in laboratory tests. ${ }^{9}$ The bricks were fitted closely together and formed a $30 \times 30 \times 90 \mathrm{~cm}(81 \mathrm{~L})$ tank. Using a $5.7 \mathrm{~cm}$ diamond core drill, a horizontal 
Table 6. Calculated Compositions of Nominal Low-Level Transuranic Waste Slags Produced in the Penberthy Electromelter. ${ }^{5}$

Oxide

$(w t \%)$

$\begin{array}{llllllll}\text { Slag Type } & \mathrm{SiO}_{2} & \underline{\mathrm{Al}}_{2} \mathrm{O}_{3} & \underline{\mathrm{Fe}}_{3} \mathrm{O}_{4}{ }^{\mathrm{a}} & \underline{\mathrm{CaO}} & \underline{\mathrm{MgO}} & \underline{\mathrm{Na}_{2}} \mathrm{O} & \underline{\mathrm{K}}_{2} \mathrm{O} \\ \mathrm{A}-0 & 38.0 & 7.4 & 34.5 & 8.3 & 4.6 & 4.8 & 2.4 \\ \text { A-20 } & 45.1 & 9.0 & 26.4 & 9.1 & 4.0 & 3.9 & 2.5 \\ \text { A-30 } & 48.2 & 9.7 & 22.8 & 9.4 & 3.8 & 3.5 & 2.6 \\ \text { A-40 } & 51.0 & 10.3 & 19.6 & 9.7 & 3.5 & 3.2 & 2.6\end{array}$

a. Total $\mathrm{Fe}$ is given as $\mathrm{Fe}_{3} \mathrm{O}_{4}$

row of 4 holes was bored through the bricks (before the bricks were assembled into the furnace.) A $7.6 \mathrm{~cm}$ layer of high temperature refractory was cast around the Ruby brick, and insulating castable was poured between this refractory and the steel furnace shell. Cores were inserted into the bored brick and extended to the furnace exterior to maintain openings in the castables for insertion of the $5 \mathrm{~cm}$ Mo electrodes. The furnace roof arches were also made with castable refractories, which were poured into reusable molds fabricated from sheet metal and plywood.

The furnace contents were poured by lifting the rear of the furnace with a crane so that it pivoted about the trunnions located at the front and the melt poured from the spout into a container. It was not intended that the furnace be emptied completely, because it was necessary to (a) maintain sufficient hot bath to cover the Mo electrodes and protect them from oxidation, and (b) to provide a hot reservoir to conduct the current and melt-in the next charge. Only about a third of the charge was poured. The remaining reservoir was large enough to make radical heat-to-heat composition changes difficult. At the end of the pour, a view through the pouring spout (while the furnace was tilted) enabled inspection of the rearmost electrodes and adjacent refractories when they were momentarily exposed.

This furnace was used for three melting campaigns. Although it was disassembled and rebuilt after the first melting campaign, many of the original major components were suitable for reuse, with only the refractories adjacent to the electrodes and the castable backing requiring replacement. Later, a smaller, or "miniature" JHM was constructed using the same basic design (see Figure 10) but which 


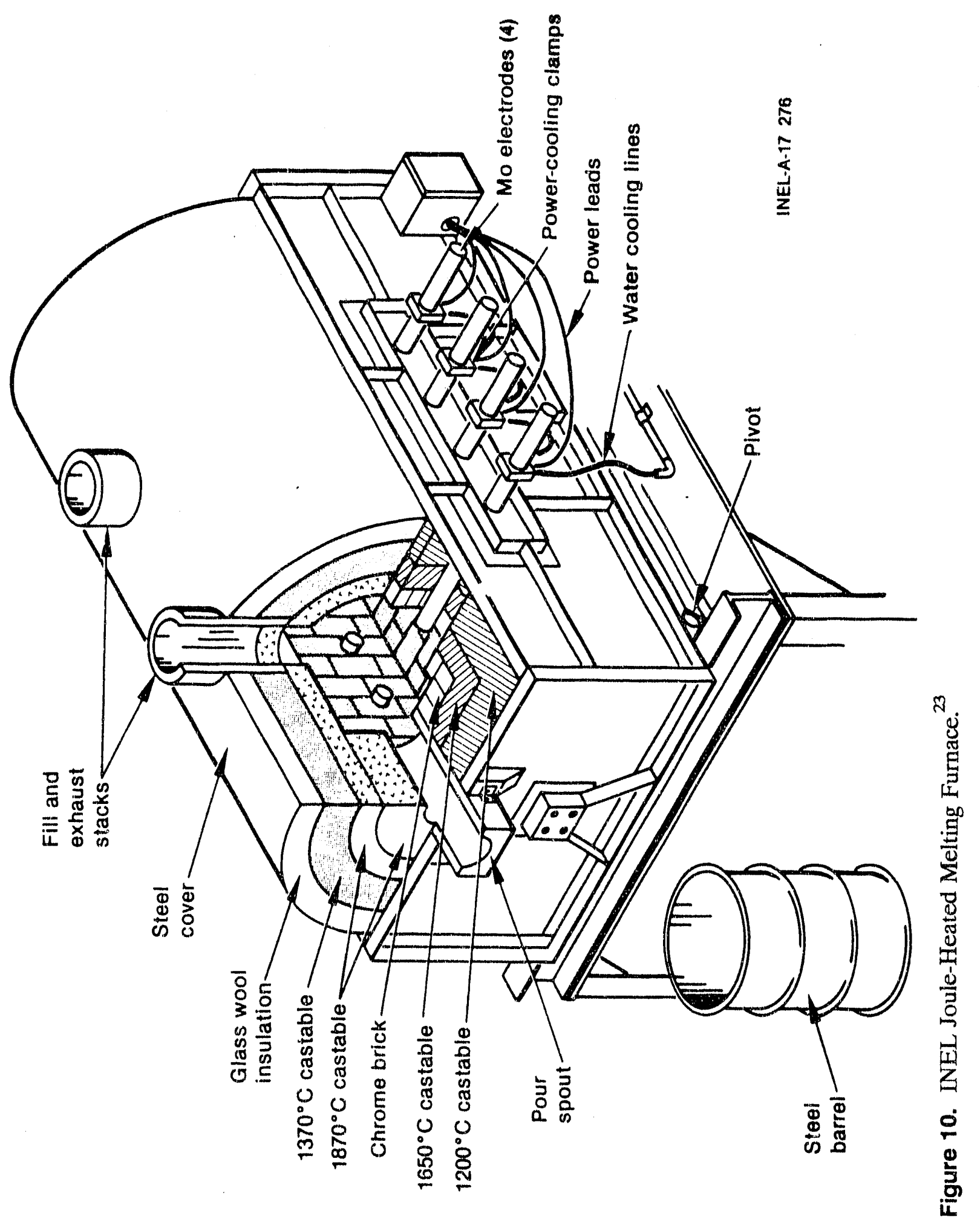


had a capacity of only $9 \mathrm{~L}$. This unit enabled JHM studies without requiring production and disposal of large quantities of IEB.

\subsection{INEL JHM Operation}

The first version of the INEL JHM had a total running time of 155 hours. A total of 8 heats were made during this campaign, with melts ranging from 150 to $225 \mathrm{~kg}$ and pours ranging from 50 to 70 $\mathrm{kg}$. The melting campaign was considered successful; however one pour melted through the side of a drum when the stream was allowed to impinge on that side for too long instead of on the drum bottom (which had a chill plate beneath it). The furnace was set at "idle" after the eighth pour (100 A to maintain a steady bath temperature of $1400^{\circ} \mathrm{C}$ ) and was maintained in this condition for about 60 hours. Then, after tilting the furnace to insperc the refractories at the rear of the melting chamber, it was noted that considerable deterioration '1ad occurred, which prompted the decision to end the first campaign. The furnace was tilted as far is possible to remove most of the residual melt and was then leveled and backfilled with silica sand to protect the electrodes from oxidation until the unit had cooled to room temperature.

The eighth heat had contained $5 \% \mathrm{CaF}_{2}$ as part of an attempt to convert simulated ICPP calcines to IEB and refractory deterioration was attributed to the dissolving power of $\mathrm{CaF}_{2}$. The Mo electrodes exhibited attrition due to oxidation, not only from contact with the bath, but also from contact with air where they emerged from the melt, passed through the furnace well while still quite hot, and were surrounded by the insulating refractory. Test bricks to compare durability of several refractory compositions were used to make the rear wall of the furnace and fared well because the rear wall was considerably cooler than the side walls that contained the electrodes.

A layer of iron was found on the bottom of the melting chamber when the last of the IEB was chipped out. This layer resulted from the $13.6 \mathrm{~kg}$ of iron that was added during the seventh melt to simulate the presence of scrap iron in the charge. After it was pried out and weighed, it was discovered that only $20 \%$ of the added iron was oxidized and dissolved into the bath during the final 100 hours of furnace operation. Oxygen from air in contact with the surface of the molten IEB diffused to the bottom of the melt in order for this oxidation to occur.

After the inspection and evaluation of the furnace, the unit was rebuilt, locating the test bricks in the chamber wall that contained the electrodes. The oxidized portions of the electrodes were cut off so the original cross section was presented to the melt. The electrodes could be reduced from the original 24-in. length to about 16 in. before they became too short to attach the power/cooling clamps.

The starting mix for the second melting campaign was $63 \%$ synthetic zeolite (IonSiv-IE95, Union Carbide Corp.), with a balance of other ingredients to produce $200 \mathrm{~kg}$ of the IEB composition. This mix was brought to temperature with the gas burner, as was done previously, and the power was applied as soon the bath became conductive. A series of small $(4 \mathrm{~L})$ castings were poured to study 
the effects of heat treatment on devitritication, and the furnace was operated for about 8 days (186 h) until difficulty was encountered with the rearmost Mo electrodes and the furnace was shut down for examination. As was done at the end of the first campaign, most of the melt was poured into a container and the exposed electrodes were covered with silica sand to minimize oxidation while the furnace was allowed to cool for eventual disassembly and examination. Removal of the furnace top was accomplished with no difficulty, the protective layer of sand was scooped out, exposing a layer of "stony" basalt that had apparently partially devitrified and was difficult to chip out and remove without damaging the refractories. Because no scrap was added and reducing conditions were not encountered during any of the melts of this series, no layer of iron was present beneath the slag.

The electrodes were loosened and removed. Again, oxidation was severe in the region inside the insulating refractory, even though Kaowool was tamped into the clearance. Two of the electrodes at the rear of the furnace had oxidized completely through the cross-sections. ${ }^{24}$ The bricks in the vicinity of the clectrodes fared rather well, although we were not able to assess brick deterioration around the electrodes themselves because this slag was left in place to form a seal around the next electrode, and attempting to remove some of this slag would likely fracture the brick. The Monofrax $\mathrm{E}$ and the K-3 bricks exhibited the least deterioration, with the Monofrax showing $0.15 \mathrm{~cm}$ loss, the K-3 bricks showing $<0.6 \mathrm{~cm}$, and the Ruby and Serv-M exhibiting $<1.3 \mathrm{~cm} \mathrm{loss.}{ }^{24}$ The bricks forming the bottom of the furnace showed no deterioration. The compositions of the bricks used in the furnace sidewall are given in Table 7.

The sidewall refractories appeared serviceable and the backup castable was chipped out from behind this refractory and replaced with new castable. New electrodes were installed where cutting off the used ones would render them too short for service, new furnace arches were cast where necessary, and the furnace was assembled and prepared for another melting campaign.

The first melt of the third melting campaign was a high-iron (12.6\%) BSG to generate material for heat treatment studies of this composition. Excess material (beyond what was needed for heat treatment) was poured into a separate container and discarded. This nearly emptied the furnace so the electrodes were exposed when the furnace was returned to level, and a new charge was added immediately. Some apprehension existed about chilling the small hot charge reservoir enough to prevent joule heating without application of the gas burner used to heat the original charge, however, the cold charge was placed in the center of the remaining melt, displacing much of it upwards into contact with the electrodes so that current could pass through the hot slag. This second melt was an "intermediate chemistry" heat to dilute the previous melt to enable production of the IEB composition during the third melt. The IEB produced in the third melt contained only $1.7 \%$ residual $\mathrm{B}_{2} \mathrm{O}_{3}$ as a result of this dilution.

The third melting campaign ended after it was noted that the outermost layer of refractory was becoming very hot. This condition was evident where the refractory was directly visible in the furnace casing port for the electrodes. Also, the electrodes were becoming loose in their recesses. When hot 
Table 7. Composition of refractory brick used in the INEL electromelter.

\begin{tabular}{lccccccc}
\hline & $\underline{\mathrm{Al}}_{2} \mathrm{O}_{3}$ & $\mathrm{Cr}_{2} \mathrm{O}_{3}$ & $\underline{\mathrm{SiO}}_{2}$ & $\underline{\mathrm{Fe}}_{2} \mathrm{O}_{3}$ & $\underline{\mathrm{MgO}}$ & $\underline{\mathrm{p}}_{2} \mathrm{O}_{5}$ & $\underline{\mathrm{Na}_{2} \mathrm{O}}$ \\
Ruby $^{\mathrm{a}}$ & 89.0 & 9.5 & 0.1 & 0.1 & 0.5 & $\ldots \ldots$ & $\ldots$ \\
Serv-M $^{\mathrm{b}}$ & 89.7 & 9.8 & 0.5 & 0.5 & $\ldots .$. & 1.0 & 0.4 \\
Monofrax E $^{\mathrm{c}}$ & 4.0 & 77.7 & 1.6 & 7.9 & 8.7 & $\ldots .$. & 0.1 \\
$\mathrm{~K}-3^{\text {c }}$ & 60.4 & 27.3 & 1.8 & 4.2 & 6.1 & $\ldots$ & 0.3
\end{tabular}

a. Pressed and sintered brick, Harbison-Walker Co.

b. Fuse-bonded brick, Didier-Taylor Refractories Corp.

c. Fused-cast brick, Carborundum Co.

slag began leaking around one of the electrodes, the power was turned off, the leak was stopped by chilling the slag with cold tongs, and the furnace was emptied and backfilled with sand. The total operating time for the third melting campaign was 520 hours; about three times the hours obtained previously. The longer time was attributed to generally lower operating temperature (1400 to $1450^{\circ} \mathrm{C}$ ).

Disassembly of the furnace disclosed that failure resulted when molten regions developed in the insulating refractory behind the chrome-alumina brick. The insulating brick is porous and not resistant to most slags, so once this condition developed in the insulating brick between the electrodes, overheating developed quickly and failure was imminent. A clue indicating that this condition is occurring is a decrease in bath temperature while voltage and current remain nearly constant. Increasing the current to recover the bath temperature hastens refractory failure.

The miniature JHM was built to study refractory life and to demonstrate the effectiveness of Mo electrode protection techniques; the two factors that seemed to be the most formidable barriers to developing a technique for producing the IEB waste form in a JHM. The miniature JHM had a $25 \times 20 \times 18 \mathrm{~cm}$ melting chamber that provided a capacity of about $9 \mathrm{~L}$ and which could pour about $4 \mathrm{~L}$ without exposing the electrodes. This provided sufficient pouring capacity to permit slag heat treating studies without having to dispose of all the excess material. The electrodes were molybdenum, 1 in. $(2.5 \mathrm{~cm})$ in diameter, and were arranged in the same pattern as the previous furnace design to permit utilization of the same power supply and controllers.

The refractory for each side of the melting chamber that contained the electrodes was made from a single slab of Monofrax E. Four alumina sleeves, $(3.2 \mathrm{~cm}$ in diameter, $3 \mathrm{~mm}$ wall thickness), were cemented into each of the refractory slabs and the sleeves extended through the insulating refractory to the furnace exterior. A 6-mm hole was bored into each sleeve and a stainless steel manifold was constructed for each side of the furnace to feed nitrogen to each of the holes. After 
the manifolds were assembled and connected to the holes, they were enclosed by pouring the outermost layer of insulating refractory around them. Kaowool was packed into the clearance between the sleeves and the electrodes thereby protecting the electrodes from contact with air where they were hot, as long as a flow of nitrogen was present and the alumina sleeves were not cracked. A nitrogen flow of $6 \mathrm{cth}$ was sufficient to protect all eight electrodes. Also, the water-cooled clamps to which the power leads were attached were fastened as close to the furnace wall as possible so that the electrodes were reasonably cool where they were exposed to the atmosphere. This arrangement worked well and the furnace was operated for 2252 hours. $^{e}$

The long melting campaign in the miniature JHM enabled conducting some of the experiments originally planned for the larger furnace. The hot bath of IEB was used to destroy ion exchange resins and to accommodate aluminum scrap by oxidizing it into alumina.

The resins were of the type used to clean up the water in the containment building at Three Mile Island. These resins were the phenolic, sulfonated, and quaternary amine types, and were new and damp when removed from their containers. When placed on top of the bath, they decomposed slowly, with the sulfonated and quaternary amine types burning with a low flame, while the phenolic type produced a large amount of oily soot that coated the furnace hood and exhaust system, and which could be ignited. Were the atmosphere over the melt enriched with oxygen, the resins would have burned more vigorously and the production of soot may have been avoided. The resins decomposed quickly when pressed beneath the melt surface, but then the bath becomes reducing and some metallic. Fe may settle out. When blown into the furnace using the educator from the gas burner, the resins ignited readily but were swept out the exhaust stack by the air currents, while others settled around the exterior of the furnace as hot embers. When allowed to decompose quietly on the bath surface, the resins could be destroyed at a rate of $1350 \mathrm{~g} / \mathrm{h}$, or, expressed on a $\mathrm{g}$ per unit area basis, $2.6 \mathrm{~g} / \mathrm{h} / \mathrm{cm}^{2}$.

About $750 \mathrm{~g}$ of aluminum was added to the melt in the fo:m of 1100 scrap and empty soft drink cans. The cans were selected because they were very thin and would oxidize readily into $\mathrm{Al}_{2} \mathrm{O}_{3}$. The $750 \mathrm{~g}$ of $\mathrm{Al}$ produced $1400 \mathrm{~g}$ of $\mathrm{Al}_{2} \mathrm{O}_{3}$ and increased the average alumina content of the bath from 11 to $18 \%$. When submerged in the IEB, the Al would oxidize quickly at the expense of the Fe oxides and produce metallic Fe. The molten Al was of lower density than the IEB and would float on the bath surface until it oxidized. This would cause the bath surface (which was always cooler than the melt beneath it by as much as $200^{\circ} \mathrm{C}$ ) to become quite refractory and bridge over, preventing the pouring of some of the melt as well as preventing additions to the melt from being made readily. This condition could be quite troublesome if larger amounts of aluminum were added and this crust allowed to build up. The situation was corrected by the addition of silica, but by the time sufficient silica was added, the melt level was higher than the pouring spout and only a frozen lava dam kept the excess in the furnace.

c. G. A. Reimann, unpublished data. 
This melting campaign was terminated because program objectives had been met and operating funds were becoming depleted; however, the Monofrax refractory around the electrodes had deteriorated to a significant extent and it was not likely that the campaign would have lasted more than an additional 100 to $200 \mathrm{~h}$ before the melt penetrated the insulating refractory. This assessment was made after disassembly of the furnace. It could not have been made by pecring into the pouring spout while the furnace was tilted because only the rearmost electrodes and the refractory at the rear of the melting chamber were visible at this time.

\subsection{Equipment Design and Durability}

Even though Monofrax E was a very durable refractory compared to the alternative refractories considered, the refractory lining remains as the limiting factor determining furnace life. This is significant when the JHM must operate remotely when processing high-ievel wastes. The furnace configurations used in this effort would be difficult to maintain and rebuild remotely. Because refractory attrition was most severe where convection currents were strongest and where the melt temperatures were highest, increased refractory life might be obtained by modifying the furnace design so that the electrodes were inserted through the furnace bottom. However, such a design is problematic because liquid metals accumulate on the furnace bottom and could short-circuit the electrodes. This situation could be controlled by a sloping bottom and a sump if enough heat could be maintained in this area to enable periodic lapping of excessive metal accumulations.

The problem with the high rate of oxidation of Mo electrodes within the refractories may have been solved by using the protective atmosphere, although the electrodes will still suffer oxidation where they are immersed in the high-iron, high oxygen conditions encountered when melting IEB. Electrode attrition in the melt may be accommodated by driving the electrodes inward periodically. The authors propose research on sensing electrode immersion electronically to eliminate reliance on visual estimation.

Nearly all of the charges introduced into the melters consisted of a uniformly sized feed, which had been carefully weighed and thoroughly blended. Retrieved RWMC waste will not produce such a homogeneous input, even after a primitive treatment to extract pieces too large to be charged into the melting unit. Except for the scrap aluminum and the resin additions, the INEL has had no experience with producing IEB in a JHM from an inhomogeneous feed. Future studies should include investigating the consequences of introducing a variety of inhomogencities, including larger pieces, into the furnace feed.

\subsection{Conclusions and Recommendations}

The RWMC wastes are in temporary storage and must be retrieved and converted into a stable waste form for storage in a permanent repository. Currently, the only approved stable waste form is BSG and that is for high-level waste; however, it does not appear feasible to convert the RWMC wastes into BSG because of the very large quantities of borax and other ingredients required to dilute 
the A-0 composition to the BSG composition, and because the temperature limit for operating the BSG JHMs will not melt ferrous scrap. Melting the waste-soil mix encountered the RWMC produces a material very similar to natural basalt (except for an elevated iron content, hence the term iron-enriched basalt), and natural basalt is recognized for its leach resistance and high mechanical properties.

BSG is produced in a JHM, however, IEB requires higher temperatures than JHM furnaces and will endure for extended periods of operation, so new materials and designs are needed to adapt the JHM concept to reliable IEB production. Other candidate processes for producing IEB are plasma heated melters (PHM) and electric arc furnaces (EAF). The INEL had direct experience in producing IEB with a JHM and encountered significant problems. Different problems must be overcome when a PHM or an EAF is considered. This situation leaves us with what appears to be a superior waste form, but currently without an effective technology for producing it.

If the RWMC waste is to be converted to the IEB waste form, the IEB must be fully characterized to enable an assessment of its ability to immobilize radioactive and hazardous waste for periods measured in geologic time, and the technology must be developed that will convert the millions of cubic feet of the RWMC waste to IEB at a cost and a rate that is acceptable. At this moment, the waste form itself is closest to being fully developed, while the technology for producing it remains in an less well-developed state. Near term efforts should concentrate on completing IEB characterization to produce a "second generation" IEB while gathering data on processing technology to enable a decision regarding a selection of a process to demonstrate on a pilot-plant scale. Future efforts on IEB should concentrate on:

- Determining the effect of composition and the $\mathrm{FeO}: \mathrm{Fe}_{2} \mathrm{O}_{3}$ ratio on nucleation and devitrification temperatures.

- Determining the minimum quantity of $\mathrm{ZrO}_{2}$ needed to precipitate baddeleyite crystals or to produce zircons.

- Determining the ability of the baddeleyite (or zircon or other equivalent durable phase) crystals to host the various TRU elements.

- Comparing leach tests on IEB and BSG with same waste loadings, but with IEB devitrified and containing $\mathrm{ZrO}_{2}$ host crystals.

- Developing the technology required to produce the IEB waste form reliably and on the scale necessary to retrieve and ship the RWMC waste to the permanent repository within the desired time frame. 


\section{REFERENCES}

1. N. D. Cox et al., Figure of Merit Analysis for TRU Waste Processing Facility at INEL, TREE-1293, October 1978.

2. D. A. Arrenholz and J. L. Knight, A Brief Analysis and Description of Transuranic Wastes in the Subsurface Disposal Area of the Radioactive Waste Management Complex at the INEL, EGG-WTD-9438, February 1991.

3. RCRA Facility Investigation Workplan, Vol. I, EGG-WM-8219, September 1, 1988.

4. C. M. Jantzen, "Systems Approach to Nuclear Waste Glass Development," Journal of Non-Crystalline Solids, 84, Elsevier Science Publishers, Amsterdam, 1986, pp. 215-225.

5. J. E. Flinn et al., Anrual Report on the TRU Waste Form Studies with Special Reference to Iron-Enriched Basalt: 1980, EGG-FM-5366, June 1981.

6. G. H. Beall and H. L. Rittler, "Basalt Glass Ceramics," Ceramic Bulletin, 55, No. 6, 1976, pp. 579-582.

7. P. C. Ragland and J. J. W. Rogers (eds.), Basalts, Van Nostrand Reinhold Co., Inc., New York 1984.

8. J. N. Fischer, Hydrogeologic: Factors in the Selection of Shallow Land Burial Sites for the Disposal of Low-Level Radioactive Waste, U.S. Geological Survey Circular 973, pg. 18.

9. J. E. Flinn, P. V. Kelsey, W. C. Seymour, and R. L. Tallman, Summary of FY 1979 Material Support Studies for SPI-Migration and Immobilization, EGG-FM-5041, September 1979.

10. S. S. Koegler et al., Vitrification Technologies for Weldon Spring Raffinate Sludges and Contaminated Soils, Phase 2 Report: Screening of Alternatives, PNL-7125, November 1989.

11. J. M. Welch, R. P. Schuman, S. P. Henslee, R. L. Tallman, and J. E. Flinn, Iron-Enriched Basalt as' a Waste Form for High Level Nuclear Wastes, EGG-FM-5758, October 1982.

12. T. D. Chikalla and J. A. Powell, Nuclear Waste Management Quarterly Progress Report, April through June 1981, PNL-3000-10, September 1981.

13. J. M. Welch, R. L. Miller, and J. E. Flinn, Fuel and Core Storage and Disposal Development: FY-82 Immobilization of Three-Mile Island Core Debris, EGG-FM-6059, Outober 1982.

14. J. G. Conley, P. V. Kelsey, and D. V. Miley, "Investigations of the properties of Iron-Enriched Basalt with TiO2 and ZrO2 Additions," Ceramics in Nuclear Waste Management, The American Ceramic Society, Chicago, IL, 1984, pp. 302-309.

15. W. A. Deer, R. A. Howie, and J. Zussman, Rock-Forming Minerals, 1, Ortho- and Ring Silicates, Longmans, London, 1962, pp. 59-68. 
16. C. Krupka, Selected Physiochemical Properties of Basaltic Rocks, Liquids and Gilasses, LA.554(). MS, March 1974.

17. L. Leibowitz of al, "Viscosity of UO ${ }_{2}$-Basalt Melts," Nuclear Technology, 24, 1974, pg. 234.

18. Pacilic Northwest Laboratory, MCC-1 Static Leach Test, August 1980.

19. J. M. Wolch, C. W. Sill, and J. E. Flinn, Leach Tests of Simulated Low Level Transuranic Waste Forms Containing Transuranic Elements, EGG-FM-6153, January 1983.

20. J. M. Wolch, R. P. Schuman, and J. E. Flinn, Immobilization of Transuranic Sludge in Glassi-Ceramic Materials, EGG-FM-5709, March 1982.

21. R. H. Nafziger and L. L. Oden "Electric Arc Furnace Melting of Simulated Transuranic Wastes," Mat. Res. Symp. Proc., 15, Elsevier Publishing Co., Inc., 1983, pp. 639-646.

22. J. A. Stone, "An Experimental Comparison of Alternate Solid Forms for Savannah River High Level Wastes," Scientific Basis for Nuclear Waste Management, 6, S. V. Topp (ed.), New York: Elsevicr Science Publishing, 1982, pp. 1-8.

23. G. A. Reimann and J, M. Welch, Electromelt Furnace Evaluation, EGG-FM-5566, September 1981.

24. M. R. Hankins, P. V. Kelscy Jr., G. A. Reimann, and S. T. Schuctz, Melting of Zeolite in a Joule-Heated Melter, RE-M-82-(K)1, January 1982. 


\section{BIBLIOGRAPHY}

\subsection{Introduction}

The majority of work on IEB was done at INEL nearly a decade ago. If this work is to be continued, a complete listing of relevant work will help researchers to study and reacquaint themselves with the subject in a short period of time. Using existing data will allow work to continue on the problem without starting over and duplicating what has already been done.

The bibliography that follows contains all the known documents and publications on ironenriched basalt completed in the late seventies and early eightics for work done at INEL or contracted out by INEL to outside organizations. The majority of the listings are contained in the INEL Technical Library. Their holdings include most of the formal, informal, and technical reports published hy EG\&G, but not lab reports. As a partial guide to the bibliography, the informal reports have report numbers like EGG-FM-xxxx and EGG-WM-xxxx, where the $x$ 's represent numbers, Internal technical reports have numbers like RE-M-yr-xxx and lab reports, LR-yr-xx-xx, where yr indicates the last two digits of the year. For convenient access, all of the listings have been incorporated into files held by the Materials Science Unit at the INEL Research Center (IRC).

\subsection{Chronological Revlew}

The following chronological review of various aspects of INEL research on IEB waste forms is provided as a route to the papers and reports that may merit further study. The RE-M-designated reports are "Internal Technical Reports" which at the time of preparation had not received patent clearance and were not to be transmitted to the public. The EGG.designated reports are Informal Reports intended for use as a preliminary or working document, and which is available externally.

- Seymour-78 (RE-M-78-033) discusses potential final waste forms including IEB and ceramics, as well as a discussion of leach theory and tests.

- Scymour-78 (RE-M-78-034) presents initial tests of TRU migration into commercial castable and plastic refractories for use with the Slagging Pyrolysis Incinerator. Plastic refractories are preferred and pore penetration is the major migration mechanism. $\mathrm{Al}_{2} \mathrm{O}_{3}$ and $\mathrm{Al}_{2} \mathrm{O}_{3}-\mathrm{Cr}_{2} \mathrm{O}_{3}$ seemed to resist chemical diffusion of 'TRU.

- Cox-79 (TREE-1293) presented a ligure of merit analysis for TRU waste processing.

- Flinn-79 (EGG-FM-5041) determined chemical composition, structure and leach resistance for slags from the Slagging Pyrolysis Incinerator.

- Malik-79 (LR-80-(49-07) investigates enamels for consolidation of TWTF (STI) slag frit.

- Miller-79 (RE-M-79-(012) discusses a potential chemical separation process for radionuclides and unit processes required. 
- Stone-79 (DP-1545) reports on preliminary evaluations of alternate forms for immobilization of Savannah River Plant high-level waste.

- Tallman-79 (RE-M-79-(K)5) reports on leaching tests of slag made from municipal waste frit. Different heat treatment was used on cooling the slag sumples.

- Flinn-80 (EGG-FM-5241) electromelted (at Penberthy) TRU/L.LW waste composition plus soil into seven $90 \mathrm{~kg}$ castings. Examinations included extent of devitrification, bulk defects, uniformity, leaching, tensile strengths, and fracture toughness.

- Flinn-80 (MRS Sci. Basis for Nuclear Waste Management, 1980) summarizes the evaluation of four $90 \mathrm{~kg}$ slag castings electromelted (at Penberthy) approximating INEL soil and wastes. Phase and microstructure, leaching and mechanical behavior are discussed.

- Henslee-80 (RE-M-80.012) describes various mechanical tests for TRU waste in IEB waste form.

- Henslee-80) (RE-M-80-013) describes viscosity measurements on A-Scries Slags.

- Henslec-80 (RE-M-80-(014) reports electrical conductivity measurements for different types of slags (A, B, C-Series).

- Henslec 80 (LR-80-(99-8) reports on electrical conductivity measurements on $A, B$, and C Series Slags from 1273-W 1773 degrees C.

- Kelsey-80 (RE-M-80-011) evaluated metallic iron additions on A-40 slag/refractory behavior from a slagging pyrolysis incinerator. Refractory corrosion, uranium migration, and slag microstructure are investigated.

- Kelsey-80 (RE-M-80-017) compares six refractorics as possible liners for the Slagging Pyrolysis Incinerator at temperatures of $1773 \mathrm{~K}$. The best refractory (10\% $\mathrm{Cr}_{2} \mathrm{O}_{3}+$ $90 \% \mathrm{Al}_{2} \mathrm{O}_{3}$ was then tested for corrosion under different operating conditions.

- Tallman-80 (LR-80-(99-(19) investigated leaching of A-Series slags.

- Tallman-80 (MSD-M-8-80) reports on the correlation of leachant analyses and weight loss measurements in the leaching of synthetic basalts.

- Welch-80 (RE-M-80-010) evaluated A-Series slags made with municipal waste frit obtained by water cooling/fracturing incinerator ash. The resultant frit was characterized by size, composition, state, and whether the water coolant would be contaminated by uranium in the ash.

- Welch-80 (RE-M-80-016) presents test results on A-Scries slags including effects of composition, annealing, and devitrification on cooling. Additions to the slag included alkali, leat, and zirconium oxides. 
- Welch-80 (RE-M-80-018) reports tests on uranium migration in A-series slags as a function of temperature gradients during cooling using autoradiography, metallography, SEM, and EDS.

- Flinn-81 (Scientific Basis for Nuclear Waste Management, 3, 1981) characterizes ironenriched synthetic basalt for TRU containment.

- Flinn-81 (EGG-FM-5366) presents the annual report on the TRU waste form studies, especially the IEB applications.

- Flinn-81 (Looseleaf notebook of view graphs) presents the IEB research program in viewgraph form for the review to the independent peer review panel.

- Henslee-81 (LR-81-09-05) assesses IEB viscosities.

- Horton-81 (RE-M-81-003) presents a preliminary study on retention of Cs in the IEB melt and during leaching.

- Kelsey-81 (LR-81-06-02) investigated chloride volatilization in IEB Melts.

- Kelsey-81 (EGG-M-5381) discuss IEB and its application to TMI and West Valley radioactive waste disposal.

- Owen-81 (EGG-WM-5484) reviews sources of TRU wastes in the U.S. and discusses potential application of IEB as the waste form.

- Owen-81 (RE-M-81-004) discusses the use of IEB as a waste form for the TMI zeolite and core debris.

- Palmour-81 (EGG-WM-5586) is the final report of the independent peer review panel of the IEB project at INEL.

- Sill-81 (LR-81-09-04) investigates volatility of cesium and strontium from a synthetic basalt.

- Welch-81 (LR-81-02-01) examines USBM Slags.

- Welch-81 (EGG-J-3181) discusses IEB as a TRU waste form. Samples were tested for leaching resistance and fracture toughness. The volatility of $\mathrm{Cs}$ and $\mathrm{Sr}$ from an IEB melt is assessed.

- Welch-81 (EGG-M-5181) reports on IEB containment of transuranic waste sludges.

- Welch-81 (EGG-M-5281) reports on IEB containment of high-level nuclear wastes.

- Reimann-81 (EGG-FM-5556) discusses electromelt furnace operation and evaluation.

- Flinn-82 (EGG-M-4282) reviews immobilizing nuclear wastes in rian-made basalt. 
- Flinn-82 (Idaho Academy of Science) presents methods of immobilizing nuclear wastes in man-made basalt to the Idaho Academy of Science.

- Hankins-82 (RE-M-82-001) uses the INEL electromelt furnace for melting zeolites and iron oxide into an IEB. Discussion includes XRD and SEM evaluation of the castings and melter operation.

- Kelsey-82 (LR-82-06-01) investigated particle size analysis of waste components.

- Kelsey-82 (Scientific Basis for Nuclear Waste Management, 4, 1982) applies the IEB waste form to TMI radioactive waste disposal. Zeolite, core debris, stainless steel, and $\mathrm{UO}_{2}$-Zircaloy dissolution tests are described.

- Owen-82 (Treatment and Handling of Radioactive Wastes Conf., 1982) presents the application of IEB to TMI radioactive waste disposal.

- Schuman-82 (EGG-FM-6045) evaluated waste forms for the immobilization of high level and transuranic wastes.

- Schuman-82 (EGG-M-07881) reports on the preparation and leaching of fullyradioactive and spiked waste forms.

- Schuman-82 (Waste Management 1982) presentation on the preparation and leaching of fully-radioactive and spiked waste forms.

- Schuman-83 (American Nuclear Society, 1983) presents leach testing of INEL waste forms in a gamma field.

- Welch-82 (LR-82-07-01) examined nodules from a rotary-kiln test of a high-metal box.

- Welch-82 (EGG-FM-5709) immobilized RFP/TRU with glass-ceramics. A 741-2 sludge with and without Am-241 was produced in a melter, followed by controlled cooling. Compositions and cooling were varied. Testing included an assessment of microstructures and leach tests, which depended on temperature and inticated differing Am-241 leach rates.

- Welch-82 (EGG-FM-5758) incorporated HLW calcines from SRL and ICPP and ion-exchange zeolite into IEB waste forms via melting. Testing included microstructure via $\mathrm{XRD}$ and SEM/EDS, fracture toughness and tensile strength, and leach tests.

- Welch-82 (Scientific Basis for Nuclear Waste Management, 4, 1982) presents IEB as a process for containment of nuclear waste.

- Conley-83 (85th Annual Am. Ceramic Soc. Meeting, 1983) presented results of how $\mathrm{TiO}_{2}$ and $\mathrm{ZrO}_{2}$ addition affect the IEB waste form properties.

- Kelsey-83 (International Metallographic Society Meeting, 1983) presented a microstructural analysis of synrock waste forms from basaltic melts. 
- Miller-83 (EGG-MS-6351) discusses scoping studies on recovery of uranium from manmade ores.

- Welch-83 (EGG-FM-6059) reports conditions for TMI core debris to be assimilated by IEB. Tests included loading limits, dissolution rate increases due to bubbling, fracture toughness, and splitting tensile strength. Recovery of uranium is also discussed.

- Welch-83 (EGG-FM-6153) reports leach tests on slag containing low level $(1 \mu \mathrm{Ci} / \mathrm{g}) \mathrm{TRU}$ (Np-237, Pu-239, Am-241, Cm-244) from a simulated slagging pyrolysis incinerator. Tests were made on the original frit, concrete monoliths made with portland cement, and vitrified monoliths of INEL soil and simulated INEL waste and RFP/TRU sludge.

- Welch-83 (2nd Int. Symp. on Ceramics in Nuclear Waste Management, 1983) presentation on immobilization of Three-Mile Island core debris.

- Downs-83 (EGG-FM-6202) discusses final waste form disposal site options and radionuclide release and migration.

- Miller-85 (Minerals \& Metallurgical Proc., 51-52, February, 1985) present dissolution effects and leach tests on two TMI waste samples in IEB.

- Oma-89 (PNL-6768) summarizes the FY-1988 support for the In Situ Vitrification study at INEL.

\subsection{Bibliography}

J. G. Conley, P. V. Kelsey, and D. V. Miley, "Investigation of the Properties of Iron-Enriched Basalt with $\mathrm{TiO}_{2}$ and $\mathrm{ZrO}_{2}$ Addition," American Ceramic Society 85th Annual Meeting, 1983.

N. D. Cox et al., Figure of Merit Analysis for TRU Waste Processing Facility at INEL, TREE-1293, September 1979.

W. F. Downs, Scientific Data Necessary to Predict Radionuclide Migration Within or Near a Mined Nuclear Repository, EGG-FM-6202, March 1983.

J. E. Flinn, P. V. Kelsey, R. L. Tallman, S. P. Henslee, and W. C. Seymour, Iron-Rich Basalt-Type Waste forms for Transuranic and Low Level Waste Containment: Evaluation of Electromelt Castings, EGG-FM-5241, April 15, 1980.

J. E. Flinn et al., Evaluation of four $90 \mathrm{~kg}$ slag castings electromelted (at Penberthy) approximating INEL soil and wastes, MRS Sci. Basis for Nuclear Waste Management, 1980).

J. E. Flinn, G. W. Gibson, M. D. McCormack, and D. E. Owen, Annual Report on the TRU Waste Form Studies with Special Reference to Iron-Enriched Basalt: 1980, EGG-FM-5366, June 1981.

J. E. Flinn et al., Iron-Enriched Basalt Peer Review, Looseleaf notebook of view graphs, INEL/EG\&G Idaho, August 1981. 
J. E. Flinn, S. P. Henslee, P. V. Kelsey, R. L. Tallman, and J. M. Welch, "Characterization of IronEnriched Synthetic Basalt for Transuranic Containment," Scientific Basis for Nuclear Waste Management, 3, J. G. Moore, (ed.), Proceedings of Third International Symposium, Annual Meeting of Materials Research Society, Boston, MA) 201, 1981.

J. E. Flinn, Immobilizing Nuclear Wastes in Man-Made Basalt, EGG-M-04282, March 1982.

J. E. Flinn, "Immobilizing Nuclear Wastes in Man-Made Basalt," Paper Presentation to Idaho Academy of Science, Ricks College, Rexburg, ID, March 26-27, 1982.

S. P. Henslee and J. E. Flinn, Mechanical Behavior of TRU Waste Forms with Special Reference to IEB, RE-M-80-012, September 1980.

S. P. Henslee and W. C. Seymour, Viscosity Measurements on A-Series Slags, RE-M-80-013, September 1980.

S. P. Henslee and W. C. Seymour, Electrical Conductivity Measurements on TWTF A-, B-, and CSeries Slags, RE-M-80-014, September 1980.

S. P. Henslee and W. C. Seymour, Electrical Conductivity Measurements on A, B, and C Series Slags from 1273-W 1773 degrees C, LR-80-09--8, October 1980.

S. P. Henslee, IEB Viscosity Assessment, LR-81-09-05, September 1981.

R. M. Horton and J. M. Welch, Preliminary Assessment of Cesium Volatility from Iron-Enriched Basalt Melts, RE-M-81-003, April 1981.

C. M. Jantzen, D. F. Bickford and D. G. Karraker, Nuclear Waste Management, Advances in Ceramics, Vol. 8, G. C. Wicks and W. A. Ross (eds.), American Ceramic Society, Columbus, OH, 1980.

P. V. Kelsey, Jr. and W. C. Seymour, Evaluation of Metallic Iron Additions on A-40 Slag/Refractory Behavior, RE-M-80-011, August 1980.

P. V. Kelsey Jr. and W. C. Seymour, Screening Tests of Refractories for use in the Transuranic Waste Treatment Facility Via Static Cup Slog Containment at 1773 K/1 Week, LR-80-09-01, September 1980.

P. V. Kelsey, Jr. and W. C. Seymour, Determination of Corrosion of A-Series Slags as a Function of Time on $10 \% \mathrm{Cr}_{2} \mathrm{O}_{3} 90 \% \mathrm{Al}_{2} \mathrm{O}_{3}$ Refractory; Determination of the Effect of.., LR-80-09-10, EG\&G Idaho, Inc., October 1980.

P. V. Kelsey, Jr., and W. C. Seymour, Slag/Refractory Interaction: Screening Tests (Part I) and 10\% $\mathrm{Cr}_{2} \mathrm{O}_{3}-90 \% \mathrm{Al}_{2} \mathrm{O}_{3}$ Refractory Corrosion Assessments (Part II), RE-M-80-017, October 1980.

P. V. Kelsey, Chloride Volatilization in IEB Melts, LR-81-06-02, June 1981.

P. V. Kelsey, Particle Size Analysis of Waste Components, LR-82-06-01, June 1982. 
P. V. Kelsey, and D. V. Miley, "Microstructural Analysis of Synrock Waste Forms from Basaltic Melts," Proceedings of the Fifteenth Annual Technical Meeting of the International Metallographic Society, Chicago, IL, April 25-26, 1983.

P. V. Kelsey, J. M. Welch, D. E. Owen, and J. E. Flinn, Iron-Enriched Basalt and Its Application to TMI and West Valley Radioactive Waste Disposal, EGG-M-5381, December 1981.

P. V. Kelsey, R. P. Schuman, J. M. Welch, D. E. Owen, and J. E. Flinn, "Iron-Enriched Basalt and Its Application to Three-Mile-Island Radioactive Waste Disposal," Scientific Basis for Nuclear Waste Management, 4, S. V. Topp (ed.), Proceedings of Fourth International Symposium, Annual Meeting of Materials Research Society, Boston, MA.

R. K. Malik, Enamels for Consolidation of TWTF (STI) Slag Frit, LR-80-09-07, October 1979.

R. L. Miller, et al., A potential chemical separation process for radionuclides and unit processes required, RE-M-79-012, 1979.

R. L. Miller, J. M. Welch, and J. E. Flinn, Scoping Studies on Recovery of Uranium from Man-Made Ores, EGG-MS-6351, August 1983.

R. L. Miller, J. M. Welch, and J. E. Flinn, "Uranium Recovery from a Nuclear Fuel Waste Form," Minerals and Metallurgical Processing, February 1985, p. 51-52.

K. H. Oma et al., Support for the In-Situ Vitrification Study at the Idaho National Engineering Laboratory: FY 1988 Summary, PNL-6768, February 1989.

D. E. Owen and J. E. Flinn, Iron-Enriched Basalt and Its Application to Three Mile Island Radioactive Waste Disposal: A Brief Review, RE-M-81-004, April 1981.

D. E. Owen, P. V. Kelsey, J. M. Welch, and J. E. Flinn, "The Application of Iron-Enriched Basalt to TMI Radioactive Waste Disposal," The Treatment and Handling of Radioactive Wastes, April 12-14, 1982, Richland, WA (To be published in Symposium Proceedings)

D. E. Owen, Application of the Iron-Enriched Basalt Waste Form for Immobilizing Commercial Transuranic Waste, EGG-WM-5484, August 1981.

H. Palmour III, R. G. Dosch, P. B. Macedo, A. J. Machiels, and D. E. Owen (ed), The Status of Iron Enriched Basalt as a Medium for Nuclear Waste Immobilization: A Report by an Independent Peer Review Panel, EGG-WM-5586, September 1981.

G. A. Reimann and J. M. Welch, Electromelt Furnace Evaluation, EGG-FM-5566, September 1981.

R. P. Schuman, et. al., Evaluation of Forms for the Immobilization Of High Level and Transuranic Wastes, EGG-FM-6045, August 1982.

R. P. Schuman, J. M. Welch, and B. A. Staples, Preparation and Leaching of Fully-Radioactive and Spiked Waste Forms, EGG-M-7881, March 1982.

R. P. Schuman, J. M. Welch, and B. A. Staples, "Preparation and Leaching of Radioactive INEL Waste Forms," Waste Management 1982, Tucson, AZ, March 8-11, 1982, March 1982. 
R. P. Schuman, "Leach Testing of Idaho National Engineering Laboratory Waste Forms in a Gamma Field," American Nuclear Society, June 1983.

W. C. Seymour and P. V. Kelsey, Immobilization of INEL Low-Level Radioactive Wastes in Ceramic Containment Materials, RE-M-78-033, November 1978.

W. C. Seymour et al., Initial tests of TRU migration into commercial castable and plastic refractories for use with the Slagging Pyrolysis Incinerator, RE-M-78-034, 1978.

C. W. Sill, Volatility of Cesium and Strontium from a Synthetic Basalt, LR-81-09-()4, December 1981.

J. A. Stone et. al., Preliminary Evaluation Of Alternate Forms for Immobilization of Savannah River Plant High-Level Waste, DP-1545, December 1979.

R. L. Tallman and J. E. Flinn, Leaching of Incinerator Slag from Municipal Waste, RE-M-79-005, March $19 \% 9$.

R. L. Tallman, Leach Test Results on A-Series Slags, LR-80-09-09, October 1980.

R. L. Tallman, Correlation of Leachant Analyses and Weight Loss Measurements in the Leaching of Synthetic Basalts, MSD-M-8-80, December 1980.

J. M. Welch and S. Y. Henslee, Slag Frit Evaluation: Municipal Waste Characterization and Analysis of Uranium Doped A-Series Slag Frit, RE-M-80-010, October 1980.

J. M. Welch and P. V. Kelsey, Phase and Structure Scoping Studies on A-Series Slags: Effects of Composition, Annealing, and Cooling on Devitrification, RE-M-80-(016, September 1980.

J. M. Welch, Uranium Homogeneity Assessments in A-Series Slags During Cooling from the Melt in the Presence of Temperature Gradients, RE-M-80-018, October 1980.

J. M. Welch, Examination of USBM Slags, LR-81-02-01, February 1981.

J. M. Welch, R. P. Schuman, C. W. Sill, P. V. Kelsey, S. P. Henslee, R. L. Tallman, R. M. Horton, D. E. Owen, and J. E. Flinn, "Iron-Enriched Basalt for Containment of Nuclear Waste," Scientific Basis for Nuclear Waste Management, 4, S. V. Topp, (ed.), Proceedings of Fourth International Symposium, Annual Meeting of Materials Research Society, Boston, MA., 1982.

J. M. Welch, R. P. Schuman, C. W. Sill, P. V. Kelsey, S. P. Henslee, R. L. Tallman, R. M. Horton, D. E. Owen, and J. E. Flinn, Iron-Enriched Basalt for Containment of Nuclear Wastes, EGG-J-3181, October 1981.

J. M. Welch, P. V. Kelsey, and S. P. Henslee, Iron-Enriched Basalt Containment of Transuranic Waste Sludges, EGG-M-5181, December 1981.

J. M. Welch, P. V. Kelsey, S. P. Henslee, and R. L. Tallman, Iron-Enriched Basalt for Containment of High-Level Nuclear Wastes, EGG-M-5281, December 1981.

J. M. Welch, Examination of Nodules from Rotary-Kiln Test of High-Metal Box, LR-82-07-01, July 1982. 
J. M. Welch, R. L. Miller, and J. E. Flinn, Fuel and Core Storage and Disposal Development: FY-82 Immobilization of Three-Mile Island Core Debris, EGG-FM-6059, June 1983.

J. M. Welch, R. L. Miller, and J. E. Flinn, "Immobilization of Three-Mile Island Core Debris," Second International Symposium on Ceramics in Nuclear Waste Management, Chicago, IL, April 25-27, 1983, April 1983. 

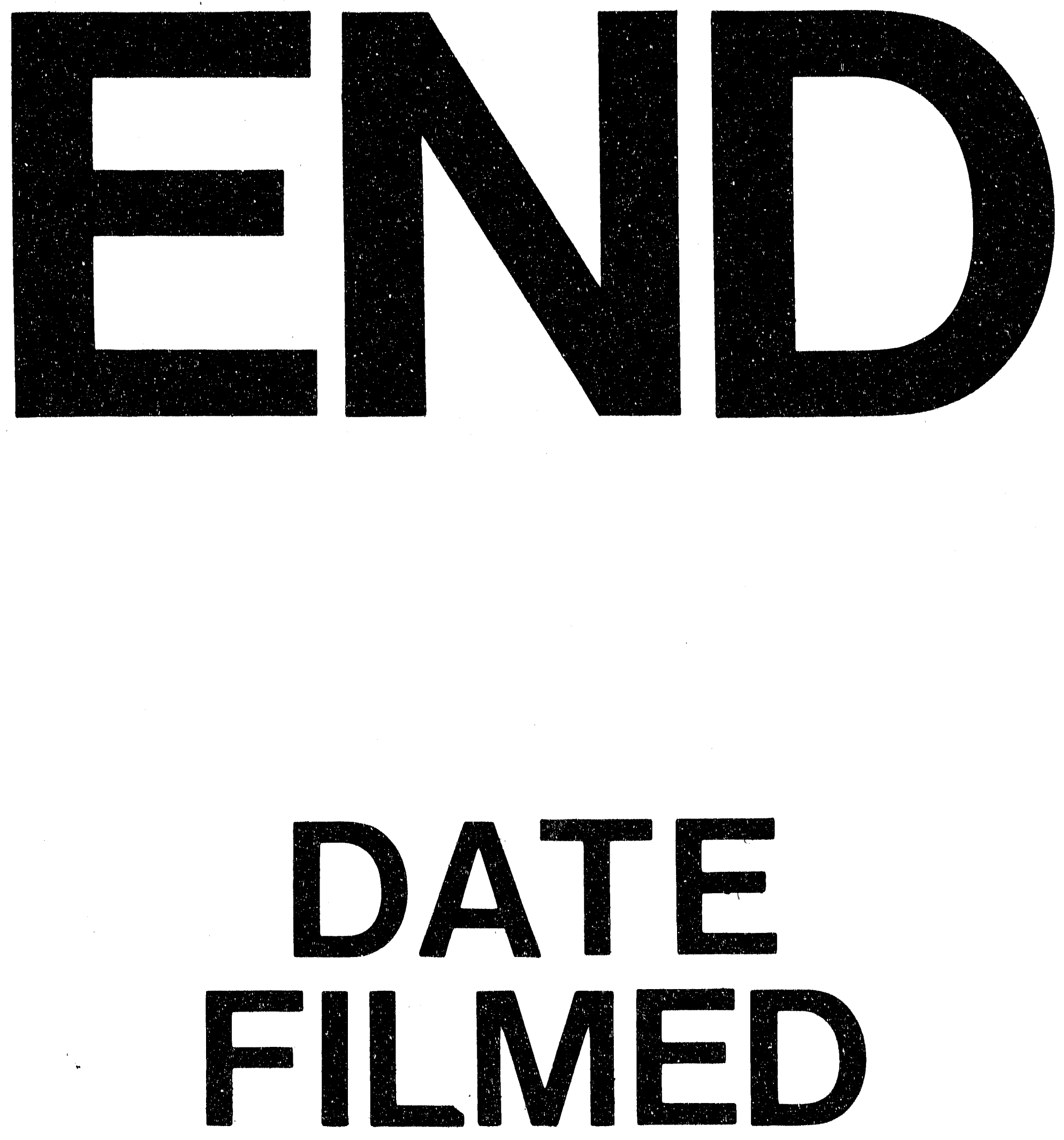

$\$$

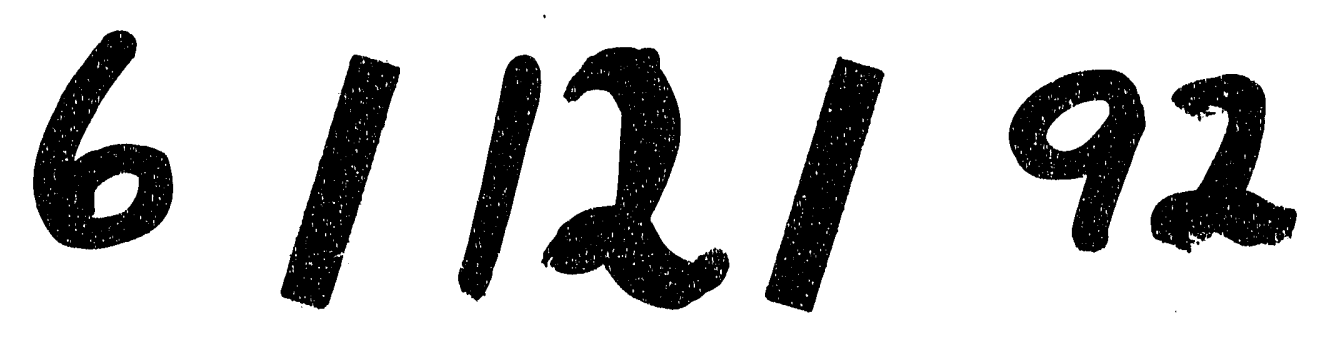


